\title{
Tracking Katz: Beepers, Privacy, and the Fourth Amendment
}

The modern policeman is assisted by a variety of electronic devices. ${ }^{x}$ Many of these devices enhance the effectiveness of law enforcement by enabling the police to see or hear what they otherwise could not. Yet these devices may also pose serious threats to Fourth Amendment values. ${ }^{2}$ One electronic mechanism that raises an especially troublesome challenge to the Fourth Amendment is the beeper.

The beeper is a miniature, battery-powered radio transmitter that emits recurrent signals at a set frequency. By covertly attaching the beeper to a subject's property and monitoring its signals with a separate receiver, the police can electronically track the property, and often the subject, for distances of several miles and for as long as several weeks. ${ }^{3}$ In its technology and secrecy the beeper closely resembles other forms of electronic surveillance. But because the beeper is capable of revealing only location and movement, it can be viewed as a sense enhancement device that is no more intrusive than traditional visual tailing. ${ }^{4}$

I. An exhaustive account of law enforcement technology is given in A. WESTIN, Privacy and Freedon 67-325 (1970). See generally S. Dash, R. Knowlton \& R. Schwartz, THE EAvesdroppers (1959) [hereinafter cited as DASH].

2. The challenges of technology to the Fourth Amendment were eloquently articulated by Justice Brandeis in his famous dissent in Olmstcad v. United States, 277 U.S. 438, 474 (1928):

"[I]n the application of a constitution, our contemplation cannot be only of what has been but of what may be." The progress of science in furnishing the Government with means of espionage is not likely to stop ... . Ways may some day be developed by which the Government, without removing papers from secret drawers, can reproduce them in court, and by which it will be enabled to expose to a jury the most intimate occurrences of the home. Advances in the psychic and related sciences may bring means of exploring unexpressed beliefs, thoughts and emotions. . . Can it be that the Constitution affords no protection against such invasions of individual security?

3. This form of bugging is briefly described in United States v. Holmes, 521 F.2d 859, 861 (5th Cir. 1975), aff'd en banc by an equally divided court, 537 F.2d 227 (5th Cir. 1976); and 29 VAND. L. REv. 514, 514 n.5 (1976). For more detailed, but somewhat dated, descriptions, see DASH, supra note 1, at 379; A. WESTIN, supra note 1, at 69-70; and Note, Anthropotelemetry: Dr. Schwilzgebel's Machine, 80 Harv. L. Rev. 403, 403 (1966).

Beepers have a sufficiently broad range to be monitored by airplane. See, e.g., United States v. Holmes, 521 F.2d 859, 863 (5th Cir. 1975), aff'd en banc by an equally divided court, 537 F.2d 227 (5th Cir. 1976); United States v. French, 414 F. Supp. 800, 802 (IV.D. Okla. 1976). In acldition to tracking location, a beeper may be used to determine when the item to which it has been attached has been disturbed. See United States v. Emery, 542 F.2d 887, 888.89 (Ist Cir. 1976). Tracking devices may have uses in contexts other than criminal investigation, particularly in the area of probation and parole. See Fried, Privacy, 77 Yale L.J. 475, 475-76, 489-93 (1968); Note, supra at 406, 408-19.

4. The view that visual observation does not infringe on Fourth Amendment rights rests in part on the famous dictum by Lord Camden that "the eje cannot . . . be 
Recently several federal and state courts have been asked to decide whether electronic tracking, like electronic eavesdropping, incurs the full panoply of Fourth Amendment protections or, like traditional tailing, needs no judicial supervision..$^{5}$ Their responses, often in conflict with one another, have failed to grasp or resolve the complex problems presented by this issue.

This Note explores the constitutional implications of electronic tracking. It first examines the inconsistent judicial decisions regarding the beeper and suggests that they result from a misapprehension of the controlling standards set in Katz $v$. United States. ${ }^{6}$ Instead of relying on the majority opinion in Katz, the courts have applied the "reasonable expectation of privacy" standard suggested in a concurring opinion. The Note attempts to resolve the Fourth Amendment issues

guilty of a trespass." Entick v. Carrington, 19 How. St. Tr. 1030, 1066 (1965) (quoted in Boyd v. United States, 116 U.S. 616, 628 (1886)). Exemption from Fourth Amendment purview has been extended to the other senses as well, and to devices, such as searchlights or binoculars, that aid the senses. See Peebles, The Uninvited Canine Nose and the Right to Privacy: Some Thoughts on Katz and Dogs, 11 GA. L. REv. 75, 97 n.93 (1976).

5. Nine reported federal cases have dealt directly with the Fourth Amendment issue. United States v. Abel, 548 F.2d 591 (5th Cir. 1977), cert. denied, 45 U.S.L.W. 3788 (U.S. June 6, 1977); United States v. Pretzinger, 542 F.2d 517 (9th Cir. 1976) (per curiam); United States v. Emery, 541 F.2d 887 (lst Cir. 1976); United States v. Hufford, 539 F.2d 32 (9th Cir.), cert. denied, 97 S. Ct. 533 (1976); United States v. Frazier, 538 F.2d 1322 (8th Cir. 1976), cert. denied, 97 S. Ct. 823 (1977); United States v. Perez, 526 F.2d 859 (5th Cir.), cert. denied, 429 U.S. 826 (1976); United States v. Holmes, 521 F.2d 859 (5th Cir. 1975), aff'd en banc by an equally divided court, 537 F.2d 227 (5th Cir. 1976); United States v. Bobisink, 415 F. Supp. 1334 (D. Mass. 1976); United States v. French, 414 F. Supp. 800 (W.D. Okla. 1976).

In several other federal cases, the record has indicated that beepers were used, but the courts have found it unnecessary to consider the search and scizure implications of electronic tracking. See United States v. Worthington, 544 F.2d 1275, 1281 (5th Cir. 1977), petition for cert. filed, 45 U.S.L.W. 3696 (U.S. Mar. 18, 1977) (No. 76-1298) (beeper placed in defendant's aircraft malfunctioned, so information was not tainted); United States v. Park, 531 F.2d 754, 763-65 (5th Cir. 1976) (trial court did not err in refusing hearing on use of beeper where government disclaimed use in this case although it had placed beeper on defendant's car in conjunction with another investigation); United States v: Bishop, 530 F.2d 1156 (5th Cir.), cert. denied, 97 S. Ct. 133 (1976) (use of beeper inserted in money bag to tail bank robbers legal under state "close pursuit" statute); United States v. Bergdoll, 412 F. Supp. 1323, 1337-38 (D. Del. 1976) (even if becper attached to defendant's car was illegal, subsequent search and arrest not tainted because based on information obtained by other means).

There have been at least three state court cases dealing with beepers. Houlihan $v$. State, 21 Crim. L. Rep. (BNA) 2315 (Tex. Crim. App. May 25, 1977) (placing beeper on van loaned to marijuana trafficker by undercover agent not violative of Fourth Amendment; alternatively, beeper not essential to investigation leading to arrest and conviction); People v. Smith, 36 Cal. Rptr. 764, 771-73 (Ct. App. 1977) (placing beeper behind dashboard of private airplane violated Fourth Amendment although airplane operator could anticipate surveillance by radar); Fotianos v. State, 329 So. 2d 397 (Fla. App. 1976) (even if use of beeper illegal, seizure of marijuana from defendant's vehicle not tainted because visual surveillance was maintained at all times).

6. 389 U.S. 347 (1967).

7. Id. at 360-62 (Harlan, J., concurring). 
raised by electronic tracking through an interpretation of Katz that avoids some of the pitfalls of the reasonable expectation of privacy test. It argues that in most situations the physical attachment of the beeper brings electronic tracking within the Fourth Amendment, and that even where attachment is permissible, monitoring the beeper may intrude on protected rights of privacy.

Although in some cases electronic tracking may be excepted from warrant requirements, in most situations a warrant should be obligatory. Furthermore, because the beeper, like the wiretap, has special characteristics of duration, continuity, and secrecy not shared by ordinary physical searches, the warrants issued for beepers should meet special requirements necessary to ensure adequate cause and particularity. To this end, the Note proposes that warrant procedures tailored to the beeper's characteristics be prescribed by statute.

\section{The Beeper Cases}

A brief description of facts and holdings of recent cases involving the beeper ${ }^{8}$ reveals the complexity of the problems to be resolved. Beepers have been used (primarily in drug investigations) ${ }^{9}$ to trace the movement of subjects on private property, along public thoroughfares, or in public airways. ${ }^{10}$ Police have attached beepers to contraband drugs discovered during border searches, ${ }^{11}$ to motor vehicles used by suspects, ${ }^{12}$ to packages or drums of chemicals, ${ }^{13}$ to airplanes, ${ }^{14}$ and to an item of personal property. ${ }^{15}$

Occasionally police have used more than one beeper in a single

8. See note 5 supra (citing cases).

9. All the cases discussed in this Note involved drug enforcement except United States v. Frazier, 538 F.2d 1322 (8th Cir. 1976), cert. denied, 97 S. Ct. 823 (1977), in which a beeper was used to track an extortioner.

10. E.g., United States v. Pretzinger, 542 F.2d 517, 519 (9th Cir. 1976) (per curiam) (airways); United States v. Hufford, 539 F.2d 32, 33-34 (9th Cir.), cert. denied, 97 S. Ct. 533 (1976) (highways); United States v. Bobisink, 415 F. Supp. 1334, 1337, 1339 (D. Mass. 1976) (highways and private property).

11. United States v. Emery, 541 F.2d 887, 888 (1st Cir. 1976); United States v. French, 414 F. Supp. $800,801.03$ (W.D. Okla. 1976).

12. United States v. Hufford, 539 F.2d 32, 33 (9th Cir.), cert. denied, 97 S. Ct. 533 (1976); United States v. Frazier, 538 F.2d 1322, 1323 (8th Cir. 1976), cert. denied, 97 S. Ct. 823 (1977); United States v. Holmes, 521 F.2d 859, 861 (5th Cir. 1975), aff'd en banc by an equally divided court, 537 F.2d 227 (5th Cir. 1976).

13. United States v. Hufford, 539 F.2d 32, 33 (9th Cir.), cert. denied, 97 S. Ct. 533 (1976); United States v. Bobisink, 415 F. Supp. 1334, 1335-36 (D. Mass. 1976).

14. United States v. Abel, 548 F.2d 591 (5th Cir. 1977), cert. denied, 45 U.S.L.W. 3788 (U.S. June 6, 1977); United States v. Pretzinger, 542 F.2d 517, 519 (9th Cir. 1976) (per curiam).

15. United States v. Perez, 526 F.2d 859, 862 (5th Cir.), cert. denied, 429 U.S. 846 (1976) (television set). 
investigation, ${ }^{\mathbf{1 6}}$ and in several cases beepers have supplemented visual tailing. ${ }^{17}$ The length of tracking operations has ranged from a few hours to several weeks. ${ }^{18}$ Tracking has often covered long distances; in one case the tracking operation crossed three state lines. ${ }^{19}$ Whatever the distance or duration of the tracking, the beepers have eventually come to rest on private property. ${ }^{20}$

In nearly every case, those attaching the beeper have done so without obtaining a search warrant. ${ }^{21}$ Most but not all courts have permitted this warrantless use. The specific holdings, however, have ranged from broad permission for warrantless electronic tracking in almost any situation ${ }^{22}$ to equally broad proscription; ${ }^{23}$ between these extremes several courts have adopted narrow grounds permitting warrantless use of beepers in limited situations such as tracking of contraband, ${ }^{24}$ or under various standard exceptions to the warrant

16. United States v. Hufford, 539 F.2d 32, 33 (9th Cir.), cert. denied, 97 S. Ct. 533 (1976); United States v. Bobisink, 415 F. Supp. 1334, 1336 (D. Mass. 1976).

17. United States v. Pretzinger, 542 F.2d 517,519 (9th Cir. 1976) (per curiam); United States v. Hufford, 539 F.2d 32, 33 (9th Cir.), cert. denied, 97 S. C.t. 533 (1976); Unitcd States v. Perez, 526 F.2d 859, 863 (5th Cir.), cert. denied, 429 U.S. 896 (1976); United States v. Holmes, 52I F.2d 859, 861 (5th Cir. 1975), aff'd en banc by an equally divided court, 537 F.2d 227 (5th Cir. 1976); United States r. Bobisink, 415 F. Supp. 1334, 1336 (D. Mass. 1976); United States v. French, 414 F. Supp. 800, 802 (W.D. Okla. 1976); Fotianos v. State, 329 So. 2d 397 (Fla. App. 1976).

18. Compare United States v. Frazier, 538 F.2d 1322, 1323 (8th Cir. 1976), cert. denied, 97 S. Ct. 823 (1977) (beeper operated from 6:30 P.M. to 3.30 P.M. following day) wilh United States v. Hufford, 539 F.2d 32, 33 (9th Cir.), cert. denied, 97 S. Ct. 533 (1976) (onc beeper operated continuously for a month).

19. United States v. French, 414 F. Supp. 800, 801-02 (WV.D. Okla. 1976) (suspects followed from Oklahoma to Arkansas and through Kansas to Colorado). Sce United States v. Abel, 54S F.2d 591, 591-92 (5th Cir. 1977), cert. denied, 45 U.S.L.W. 3788 (U.S. June 6,1977 ) (tracking of airplane from Florida to Bahamas); United States v. Pretzinger, 542 F.2d 517, 519 (9th Cir. 1976) (per curiam) (airplanc followed from Tucson, Arizona to Mexico and back to Buckeye, Arizona); United States v. Holmes, 521 F.2d 859, $861-62$ (5th Cir. 1975), aff'd en banc by an equally divided court, 537 F.2d 227 (5th Cir. 1976) (tracking from Gainesville, Florida to a point 60 miles east).

20. E.g., United States r. Hufford, 539 F.2d 32, 33 (9th Cir.), cert. denied, 97 S. Ct. 533 (1976) (bugged chemical drum taken into private rented garage); United States v. Holmes, 521 F.2d 859, 862 (5th Cir. 1975), aff'd en banc by an equally divided court, 537 F.2d 227 (5th Cir. 1976) (bugged van driven onto private farm).

21. A warrant was obtained prior to placement of the beeper in United States v. Pretzinger, 542 F.2d 517, 519 (9th Cir. 1976) (per curiam), although the court held that this precaution was unnecessary. A warrant was obtained for placement of the second of two beepers in United States v. Hufford, $539 \mathrm{~F} .2 \mathrm{~d} \mathrm{32,38}$ (9th Cir.), cert. denied, $97 \mathrm{~S}$. Ct. 533 (1976).

22. United States v. Hufford, 539 F.2d 32, 33-34 (9th Cir.), cert. denied, 97 S. Ct. 533 (1976).

23. United States v. Holmes, 521 F.2d 859, 864-65 (5th Cir. 1975), aff'd en banc by an equally divided court, 537 F.2d 227 (5th Cir. 1976); United States r. Bobisink, 415 F. Supp. 1334, 1338-39 (D. Mass. 1976).

24. United States v. Emery, 541 F.2d 887, 889.90 \& n.6 (Ist Cir. 1976); United States v. Perez, 526 F.2d 859, 863 (5th Cir.), cert. denied, 429 U.S. 846 (1976) (warrantless tracking of illegally obtained goods; validity assumed without deciding); United States r. French, 414 F. Supp. 800, 803 (WV.D. Okla. 1976). 
requirement."5 In reaching their holdings, the courts have examined one or both of the two stages of a beeper's use: attachment of the beeper, and monitoring of its location. Each has been viewed as a potential infringement of Fourth Amendment rights. ${ }^{26}$

\section{A. Attachment}

Courts have differed concerning the degree to which the attachment of a beeper to private property implicates the Fourth Amendment. ${ }^{27}$ One approach scrutinizes the circumstances surrounding the attachment: if the installation of the beeper is legal, then its continuing presence on the property does not impinge on Fourth Amendment rights. ${ }^{28}$ As a result, the strategy of installation may be important. For

25. United States v. Frazier, 538 F.2d 1322, 1324-25 (8th Cir. 1976), cert. denied, 97 S. Ct. 823 (1977) (automobile and hot pursuit exceptions); United States v. French, 414 F. Supp. 800, 804 (W.D. Okla. 1976) (exigent circumstances). Exceptions to the warrant requirement and their applicability to electronic tracking are discussed at pp. 1496-1502 infra.

26. Although most courts have noted the relevance of both attachment and monitoring to Fourth Amendment analysis, not all courts have treated the two issues separately. Compare United States v. Hufford, 539 F.2d 32, 33-34 (9th Cir.), cert. denied, 97 S. Ct. 533 (1976) (attachment and monitoring issues subsumed under general question of reasonable expectation of privacy) with United States v. French, 414 F. Supp. 800, 803 (W.D. Okla. 1976) (explicitly separate treatment).

27. The courts agree that a physical intrusion prior to attachment invalidates the entire process. See, e.g., United States v. Hufford, 539 F.2d 32, 34 (9th Cir.), cert. denied, 97 S. Ct. 533 (1976) (upholding placement of second beeper pursuant to court order: "Had the agents not resorted to a warrant, entrance into the garage and the opening of the truck's hood would have been an invasion of an area in which Hufford had a reasonable expectation of privacy.")

In most of the cases decided thus far, however, the police legally gained access to the property to which the beeper was attached. In most instances attachment occurred in a public location. E.g., United States v. Frazier, 538 F.2d 1322, 1323 (8th Cir. 1976), cert. denicd, 97 S. Ct. 823 (1977) (attachment to automobile occurred in hotel parking lot); United States v. Holmes, 521 F.2d 859, 861 (5th Cir. 1975), aff'd en banc by an equally divided court, 537 F.2d 227 (5th Cir. 1976) (attachment to van occurred while van parked in public parking lot). Cf. United States v. Emery, 541 F.2d 887, 888-89 (1st Cir. 1976) (beeper attached during course of legal border search). But see Pcople v. Smith, 136 Cal. Rptr. 761, 767, 773 (Ct. App. 1977) (attachment of beeper behind airplane dashboard violated owner's privacy). In other cases the police made the attachment on private property to which they were admitted by consent. E.g., United States v. Abel, 548 F.2d 591, 591 (5th Cir. 1977), cert. denied, 45 U.S.L.W. 3788 (U.S. June 6, 1977) (beeper attached to airplane with owner's consent to track bailee's movements); United States $v$. Bobisink, 415 F. Supp. 1334, 1335-36 (D. Mass. 1976) (attachment to package of chemicals made at plant with manufacturer's consent). For further discussion of consent and beeper searches, see pp. $1485,1489 \&$ notes $116 \& 138$ infra.

28. United States v, Hufford, 539 F.2d 32, 34 (9th Cir.), cert. denied, 97 S. Ct. 533 (1976) (attachment to drum of chemicals occurred with consent of chemical manufacturers before delivery to defendants); United States v. Perez, 526 F.2d 859, 863 (5th Cir.), cert. denied, 429 U.S. 846 (1976) (attachment to telerision traded by undercorer agents for drugs occurred when set was in rightful possession of police). Because in both cases the beepers were attached before the property came into the defendants' possession, the 
example, if a beeper is legally placed on the property before it comes into a suspect's possession, then the placement of the beeper remains legal, even though attachment subsequent to acquisition might have been an unreasonable search.

A second approach measures the intrusiveness of attachment according to the nature of the item to which the beeper is attached. This approach has been used to validate attachment of beepers to vehicles on the theory that such property is subject to "lesser" expectations of privacy, ${ }^{29}$ and to contraband on the theory that the illegality of possession eliminates privacy interests in the physical "security" of the property. ${ }^{30}$

A third approach holds that warrantless attachment of a beeper to private property is a per se intrusion on Fourth Amendment rights. The leading case for this position is United States $v$. Holmes. ${ }^{31}$ There

Hufford and Perez courts found that placement of the beepers did not intrude upon the defendants' privacy. But see p. 1485 infra (arguing that attachment becomes search at point of transfer to defendants).

29. United States v. Frazier, 538 F.2d 1322, 1324 (8th Cir. 1976), cert. denied, 97 S. Ct. 823 (1977). A similar view was approved in United States v. Hufford, 539 F.2d 32, 33.34 (9th Cir.), cert. denied, 97 S. Ct. 533 (1976), and argued by the seven dissenters in United States v. Holmes, 537 F.2d 227, 229-30 (5th Cir. 1976) (en banc; per curiam) (Ainsworth, J., dissenting). See United States v. Pretzinger, 542 F.2d 517, 520 (9th Cir. 1976) (per curiam) (applying Hufford to airplanes). This argument rests on recent Supreme Court decisions finding privacy interests in mobile vehicles to be of a constitutionally inferior order. E.g., Cardwell v. Lewis, 417 U.S. 583 (1974). But see pp. 1487-88 infra (arguing that Fourth Amendment status of automobiles does not justify warrantless attachment of beepers to vehicles).

30. United States v. Emery, 541 F.2d 887, 888-89 (1st Cir. 1976); United States v. French, 414 F. Supp. 800, 803 (W.D. Okla. 1976). See note 131 infra (discussing Fourth Amendment status of contraband).

31. 521 F.2d 859 (5th Cir. 1975), aff'd en banc by an equally divided court, $537 \mathrm{~F} .2 \mathrm{~d}$ 227 (5th Cir. 1976). The court noted that beepers can be attached to persons as well as property, and it expressed concern that this particularly intrusive use of the device might become commonplace if attachments to property were not carefully restricted. Id. at 866 .

The sequence of decisions in Holmes deserves a brief explanation. On motions to suppress evidence seized from a van owned by one defendant and from a farm owned by two others, the district court held that warrantless use of a beeper violated the Fourth Amendment, that all the evidence seized was a fruit of the search, and alternatively that the evidence taken from the farm must also be suppressed because of an illegal trespass by police. The district court did not consider whether all nine defendants had standing to protest these searches because it erroneously believed this issue to be conceded by the Government. Id. at 863-64. On appeal, a panel of the Fifth Circuit affirmed the district court's rulings on the illegality of the two searches and the suppression of evidence, but reversed on the issuc of standing, determining that three defendants lacked standing to cliallenge use of the beeper. $I d$. at $864,867,868,870$. At the en banc rehearing, the appeal was argued de novo, and the court affirmed by equal division the district court's conclusions with respect to the scarch and adopted by a majority the pancl's opinion with respect to standing. 537 F.2d at 227-28.

Thus the en banc decision effectively affirmed the result of the panel's decision concerning the scarch and both the reasoning and the result of the panel's decision concerning standing, although technically it was not an appeal from the panel decision. See 
the Fifth Circuit distinguished the attachment of a beeper from such "minimal intrusions" as checking vehicle identification numbers and taking paint scrapings: unlike these momentary intrusions, a beeper remains constantly in place, performing a search of substantial duration and scope. ${ }^{32}$ Emphasizing the interrelationship between the beeper's physical presence and its function, the court compared the beeper to the presence of a hidden police officer. ${ }^{33}$ From this perspective not only the initial placement of the beeper but also its attachment during the entire period of use is relevant to Fourth Amendment inquiry. What begins as a legal search may subsequently become illegal if at any time the original justification for attachment becomes inapplicable. ${ }^{34}$

\section{B. Electronic Monitoring}

The courts have also disagreed over the Fourth Amendment issues raised when police monitor the movements of persons or property. At one pole stands the view that electronic monitoring does not invade a reasonable expectation of privacy when it tracks travel in public. For example, in United States $v$. Hufford ${ }^{35}$ the Ninth Gircuit held that an individual who enters a public thoroughfare surrenders his right to keep his movements, or those of property he takes with him, secret. It found "no distinction" between an electronic monitor and visual

Western Pac. R.R. Case, 345 U.S. 247, 258-59 (1953) (rejecting suggestion that rehearing en banc is a "'horizontal' appeal"); Note, En Banc Hearings in the Federal Courts of Appeals: Accomodating Institutional Responsibilities (Part I), 40 N.X.U. L. REv. 563, 599 (1965) (rehearing en banc "fully reconsider[s] the panel decision" but its effect is "to supplant, rather than to reverse or affirm, the panel decision").

32. 521 F.2d at 864-65.

39. Id. at $865 \mathrm{n.11}$.

34. Id. at 868. A beeper's continuing presence on private property was also considered relevant in United States v. Bobisink, 415 F. Supp. 1334, 1336-38 (D. Mass. 1976). The court held that a beeper attached to a package before purchase by the defendants violated their constitutional rights as soon as the package was received: "A citizen is entitled to assume that property he buys does not contain an electronic spy." Id. at 1338.

Throughout the ensuing discussion, it should be noted that Holmes and Bobisink, though still good law, may have been implicitly limited by subsequent decisions in their respective circuits. See United States v, Abel, 548 F.2d 591, 592 (5th Cir. 1977), cerl. denied, 45 U.S.L.W. 3788 (U.S. June 6, 1977) (no Fourth Amendment violation where legally effective consent to original installation of beeper on airplane; Holmes not discussed); United States v. Emery, 541 F.2d 887 (1st Cir. 1976) (no Fourth Amendment violation where beeper attached to contraband; Bobisink decision cited without discussion); United States v. Percz, 526 F.2d 859 (5th Cir.), cert. denied, 429 U.S. 846 (1976) (no Fourth Amendment violation where beeper attached prior to defendant's possession; distinguishing Holmes prior to en banc affirmance); cf. Houlihan v. State, 21 Crim. L. REs. (BNA) 2315 (Tex. Crim. App. May 25, 1977) (bugged ran loancd by undercover agent to suspected marijuana dealer did not violate Fourth Amendment; court found Perez more applicable precedent than Holmes).

35. 539 F.2d 32 (9th Cir.), cert. denied, 97 S. Ct. 533 (1976). 
observation $^{36}$ because the beeper only conveyed with precision information already available to the police without a warrant. ${ }^{3 i}$

The courts in Holmes and United States v. Bobisink ${ }^{38}$ took a completely contrary position, the Holmes court stating that although an individual in public "can anticipate visual surveillance," he does not thereby expose his location to electronic surveillance. ${ }^{39}$ These courts identified several characteristics of electronic tracking that make it more intrusive than visual observation, ${ }^{40}$ including the physical attachment of the beeper, the continuity and duration of monitoring, ${ }^{41}$ and the capacity of a beeper to track location on private property as well as in public. ${ }^{42}$ The Holmes court also noted that an individual has no way to protect himself from electronic monitoring. ${ }^{43}$

Between these two poles is a middle ground occupied by several cases involving beepers attached to contraband. In these cases the courts took the position that the beeper maintains surveillance only over the contraband itself; any tracking of individuals was treated as incidental, uncoerced, and therefore irrelevant to Fourth Amendment

36. Id, at 34 .

37. The court compared electronic tracking to the use of binoculars, tracking dogs, and searchlights, all of which have been held to fall outside the scope of the Fourth Amendment. Id. See United States v. Lee, 274 U.S. 559 (1927) (searchlight); United States v. Solis, 536 F.2d 880 (9th Cir. 1976) (dogs); Fullbright v. United States, 392 F.2d 432 (10th Cir.), cert. denied, 393 U.S. 830 (1968) (binoculars). In Solis, howerer, the court differentiated sense enhancement devices from "sophisticated modern mechanical or clectronic devices." 536 F.2d at 882 . Moreover, in another "dog" case, United States v. Bronstein, 521 F.2d 459 (2d Cir. 1975), cert. denied, 424 U.S. 918 (1976), Judge Mansficld distinguished between devices, such as electronic bugs, which replace the senses and those, such as binoculars, which aid them. Id. at 464 (concurring opinion). See Peebles, supra note 4 , at $90-91$.

38. 415 F. Supp. 1334 (D. Mass. 1976).

39. 521 F.2d at 866. See United States v. Bobisink, 415 F. Supp. 1334, 1339 (D. Mass. 1976).

40. 521 F.2d at $866 \mathrm{n} .13$ (tracking would not have been used but for its capacity to convey information beyond the limits of visual observation); 415 F. Supp. at 1339 (electronic tracking "goes far beyond any ordinary powers of observation").

41. 521 F.2d at 866; 415 F. Supp. at 1339. In Bobisink, the court opined:

Presumably, no technological problem prevents agents from placing such devices on, for example, a person's clothing. Thus, an individual could be traced on a moment to moment basis as he went about his daily activities. It offends common sense to suggest that such a continuous electronic surveillance would not violate any reasonable expectation of privacy. To allow such indiscriminate monitoring could conceivably be the prelude to sanctioning a "1984" network of such beepers connected to a master monitoring station which would keep track of each of our movements for the benefit of the powers that be. Certainly the average, reasonable citizen, with his reasonable expectation of privacy, would take little solace in the fact that, while Id.

his every movement was recorded, his conversations were not.

42. 521 F.2d at 868 (beeper invaded privacy of owners and occupants when taken onto private farm); $415 \mathrm{~F}$. Supp. at 1337,1339 (beeper used to confirm whereabouts of property secluded on private premises).

43. 521 F.2d at 865 . 
considerations. ${ }^{44}$ Moreover, tracking limited to contraband was held not to violate the Fourth Amendment because the illegal character of the goods eliminates any "reasonable expectation" that they will not be bugged. ${ }^{45}$

\section{A Search for Standards: Reinterpreting Katz}

\section{A. The Katz Majority and the Harlan Legacy}

As every court considering the problem has recognized, determination of the beeper's Fourth Amendment implications depends on a proper interpretation of the Supreme Court's holding in Katz $v$. United States. ${ }^{46} \mathrm{Katz}$ modified a long line of cases that determined the validity of searches and seizures by electronic surveillance primarily by reference to property rights. ${ }^{4 \tau}$ Before $\mathrm{Katz}$, electronic interception of oral communications was permitted so long as the techniques employed did not physically invade a "constitutionally protected area." $\$$ s

44. This view is most evident in United States v. French, 414 F. Supp. 800, 803 (W.D. Okla. 1976). The court rejected the contention that the defendants' privacy of movement was invaded: "[The beeper's] use in this case was for the purpose of tracking marijuana. It was only coincidental that it came to rest in the particular truck and that [the defendant] happened to be the driver. Its use was aimed not at keeping track of [the defendant] or the truck as such." Id. See United States v. Emery, 541 F.2d 887, 889-90 (Ist Cir. 1976) (beeper used to track parcel of drugs; concurrent tracking of persons not considered); United States v. Perez, 526 F.2d 859, 863 (5th Cir.), cert. denied, 429 U.S. 846 (1976) (beeper attached to television set exchanged for drugs was monitored only to identify property in manner similar to use of marked bills).

45. See United States v. Emery, 541 F.2d 887, 889 (1st Cir. 1976) (tracking permissible since item constructively seized at border); United States v. Perez, 526 F.2d 859, 863 (5th Cir.), cert. denied, 429 U.S. 846 (1976) (monitoring a direct result of criminal transaction).

46. 389 U.S. 347 (1967).

47. See Note, From Private Places to Personal Privacy: A Post-Katz Study of Fourth Amendment Protection, 43 N.X.U. L. REv. 968, 968-78 (1968). Property, it should be stressed, has nerer been the sole touchstone of Fourth Amendment rights. The Supreme Court recognized in the early case of Boyd v. United States, 116 U.S. 616 (1886), that the principles of "constitutional liberty and security" on which the Fourth Amendment is based "apply to all invasions on the part of the government and its employés of the sanctity of a man's home and the privacies of life." Chief among these fundamental principles are "personal security, personal liberty and private property." Id. at 630.

48. The concept of constitutionally protected areas has its roots in the more rigid "trespass" doctrine developed in Olmstead v. United States, 277 U.S. 438 (1928). See Scoular, Wiretapping and Eavesdropping Constitutional Development from olmstead to Katz, 12 ST. Louis U.L. REv. 513, 516, 523-25, 526 (1968) (concept of constitutionally protected area developed to avoid overruling olmstead). See generally J. LANDYNSKI, SEARCH And Seizure and the Supreme Court 198-244 (1966). The emergence of the new concept from the "trespass" doctrine can be traced in Goldman v. United States, 316 U.S. 129 (1942); On Lee v. United States, 343 U.S. 747 (1952); Irvine v. California, 347 U.S. 128 (1951); and Silverman v. United States, 365 U.S. 505 (1961). But see Clinton v. Virginia, 377 U.S. 158, 158 (1964) (per curiam) (Clark, J, concurring) (basing concurrence on finding that trespass took place). For a sampling of the vigorous scholarly criticism the 
This approach proved to be inadequate, however, because it required fine distinctions concerning the degree of "penetration" necessary to cause a Fourth Amendment violation. Often the legal result turned more on the type of device available to the police than on the effective reach of the surveillance itself. ${ }^{49}$

Katz represents an extension of Fourth Amendment protection beyond the limits of the doctrine of constitutionally protected areas. The case involved electronic interception of telephone conversations conducted from a public telephone booth. Litigation in the lower courts and argument before the Supreme Court had debated whether the surveillance involved physical intrusion into a constitutionally protected area. ${ }^{50}$ The Court, however, departed from this standard on the ground that it deflected attention from the real Fourth Amendment issues at stake. ${ }^{51}$

Starting from the proposition that "the Fourth Amendment protects people, not places," 52 the Court focused its inquiry on the defendant's privacy rather than on location of the bug. ${ }^{53}$ The Court rejected the theory that privacy interests must be bound to property rights. ${ }^{54}$ It held that privacy may also inhere in intangibles, such as the defendant's conversations, and that an individual may be entitled to Fourth Amendment protections in public areas as well as in the privacy of the home.

physical trespass doctrine received, see authorities cited in 13 VILL. L. REV. 643, 644 nn.108-11 (1968).

The term "constitutionally protected area" was first used as a formal criterion in Lanza v. New York, 370 U.S. 139, 142-44 (1962). Rather than relying on strict concepts of ownership, this approach attempted to accommodate privacy interests by analogizing them to property rights. An area would be constitutionally protected, for examplc, if it possessed characteristics similar to those of a house. See Kitch, Katz $v$. United States: The Limits of the Fourth Amendment, 1968 Sur. Cr. Rev. 132, 136; Note, supra note 47, at $969-71$.

49. Silverman v. United States, 365 U.S. 505, 512-13 (1961) (Douglas, J., concurring). See Dash, Katz-l' 'ariations on a Theme by Berger, 17 CATH. U.L. REv. 296, 307-11 (1968).

One commentator has suggested that judicial reliance on property rights lasted as long as it did primarily because Congress enacted legislation in 1934 to control the use of wiretapping. Only as "bugging" devices that did not require interference with telephone wires came into widespread use did the inadequacies of the Olmstead doctrine begin to assume their full significance. J. LANDYNSK, supra note 48, at 205-06, 243-44.

50. 389 U.S. at 348-49. See Brief for Petitioner at 12-13, Katz v. United States, 389 U.S. 347 (1967); Brief for Respondent at 14-15, Katz v. United States, supra.

51. 389 U.S. at $350-51$.

52. Id. at 351 .

53. Id. at 350. The Court cautioned, however, that the Fourth Amendment does not announce a "general constitutional 'right to privacy," that its protections may "go further," and that they may "have nothing to do with privacy" in certain circumstances. $I d$.

54. Id. at 353 . 
These considerations led the Court to articulate the following general rule:

What a person knowingly exposes to the public, even in his own home, is not a subject of Fourth Amendment protection. . . . But what he seeks to preserve as private, even in an area accessible to the public, may be constitutionally protected. ${ }^{5 j}$

Applying this reasoning to the facts before it, the Court found that by shutting the door to the booth and by paying for the call ${ }^{56}$ the petitioner had taken steps to exclude "the uninvited ear"; that he had "justifiably relied" on the privacy of his conversations; and that he was therefore "entitled" to protection from electronic surveillance. ${ }^{57}$ As a result, use of the bugging device represented "a 'search and seizure' within the meaning of the Fourth Amendment."ss

In applying Katz, lower courts have reduced its holding to a "reasonable expectation of privacy" formula. Yet the phrase appears nowhere in the Court's opinion. Rather, it is drawn from Justice Harlan's concurrence, ${ }^{59}$ which attempted to limit the majority's departure from precedent and to inject personal intentions and social norms into the determination of Fourth Amendment protection. Justice Harlan discerned in the prior cases a two-part test for determining the privacy interests to which the Fourth Amendment extends: first, "a person [must] have exhibited an actual (subjective) expectation of privacy"; ${ }^{\circ}$ and second, this expectation must be one "that society is prepared to recognize as 'reasonable.' "61 Although Justice Harlan agreed with the majority that Fourth Amendment rights are personal, he argued that to determine whether a particular privacy interest is deemed reasonable by society generally requires "reference to a 'place." "62 To expect privacy for a conversation in an open field, for example, would in Harlan's view have been "unreasonable." 63 Indeed, surveillance of Katz's conversations would not have been restricted by the Fourth

55. Id. at 351-52 (citations omitted).

56. Id. at 352 .

57. Id. at $352,353,352$. As further evidence of entitlement, the Court also mentioned the "vital role that the public telephone has come to play in private communication." Id. at 352 .

58. Id. at 353 .

59. Id. at 360.62 (Harlan, J., concurring).

60. Id. at 361. Harlan's test thus would deny Fourth Amendment protection where an individual cxhibits "no intention" to keep matters private. $I d$.

61. Id.

62. Id.

63. Id. at 360,361 (citing Hester v. United States, 265 U.S. 57 (1924)). 
Amendment, Harlan intimated, without the physical manifestations of privacy provided by the enclosed booth. ${ }^{04}$

\section{B. The "Reasonable Expectation of Privacy": A Critique}

Although Justice Harlan's attempt to read the significance of physical location back into the Fourth Amendment's concept of privacy has not entirely succeeded, ${ }^{65}$ his test has survived. Most lower courts apply the test as if it were controlling precedent, often without reference to the distinct rule of the majority opinion. ${ }^{66}$ When a Fourth

64. Harlan agreed with the majority because he found the petitioner's acts in shutting the door and placing the call sufficient to create a "temporarily private place whose momentary occupants' expectations of freedom from intrusion are recognized as reasonable." $I d$. at 361 .

65. See, e.g., United States v. Chadwick, 45 U.S.L.W. 4797, 4799 (U.S. June 21, 1977) (personal belongings secured in locked trunk protected from warrantless search during public transit); Cardwell v. Lewis, 417 U.S. 583, 591 (1974) (plurality opinion of Blackmun, J.) (travel in public does not waive Fourth Amendment protections); Terry v. Ohio, 392 U.S. 1, 9 (1968) (pedestrians on public street entitled to Fourth Amendment protection). Nonetheless, lower courts have frequently continued to limit Fourth Amendment protection substantially to "constitutionally protected areas." See Note, Katz and the Fourth Amendment: $A$ Reasonable Expectation of Privacy or, A Man's Home Is His Fort, 23 Clev. Sr. L. Rev. 63, 80-81 (1974) (citing cases) [hereinafter cited as Note, $A$ Man's Home Is His Fort]; Note, The Reasonable Expectation of Privacy-Katz v. United States, A Postscriplum, 9 Ind. L. Rev. 468, 471, 493-96 (1976) (citing cases). Both of the preceding commentaries support the continuing relevance of "place" in balancing privacy interests.

Harlan's view that conversations in open areas are not protected from electronic interception was adopted by Congress in its wiretapping legislation. See 18 U.S.C. $\$ 2510(2)$ (1970); S. REp. No. 1097, 90th Cong., 2d Scss. 90 (1968), reprinled in [1968] U.S. CovE Cong. \& AD. NEws 2112, 2178.

66. No Supreme Court decision has ever explicitly adopted Harlan's test, although the test has frequently been cited with approval. Perhaps the closest approach to formal acceptance came in Terry v. Ohio, 392 U.S. 1 (1968), where the Court cited Kalz for the proposition that “ 'the Fourth Amendment protects people, not places,' and wherever an individual may harbor a reasonable 'expectation of privacy,' he is entitled to be frec from unreasonable governmental intrusion." $I d$. at 9 (citations omitted). In Unitcd States v. White, 401 U.S. 745 (1971), Justice White, writing for four members of the Court, blended Justice Harlan's concept of "reasonable expectation" with the Katz majority's concept of "justifiable reliance":

Our problem is not what the privacy expectations of particular defendants in particular situations may be or the extent to which they may in fact have relied on the discretion of their companions. . . Our problem, in terms of the principles announced in $\mathrm{Katz}$, is what expectations of privacy are constitutionally "justifiable" -what expectations the Fourth Amendment will protect in the absence of a warrant. Id. at 751-52 (plurality opinion).

The "reasonable expectation" concept has been cited repeatedly by the Supreme Court in a conclusory fashion. See, e.g., Nixon v. Administrator of General Services, 45 U.S.L.W. 4917, 4926 (U.S. June 28, 1977) (the "pattern of de facto Presidential control" of personal presidential papers and "congressional acquiescence" therein gave former President Nixon a "legitimate expectation of privacy in such materials. Katz v. United States, 389 U.S. 347, 351-353 (1967)"); Cardwell v. Lewis, 417 U.S. 583, 591 (1974) (plurality opinion of Blackmun, J.) (taking of paint scraping from automobile not a Fourth Amendment search: "we fail to comprehend what expectation of privacy was infringed"); United 
Amendment right is asserted, courts generally have inquired only whether the facts of the case, taken as a whole, justified a "reasonable expectation" that the matter sought to be preserved as private would be protected from warrantless governmental intrusion..$^{6 \bar{T}}$

This use of the Harlan test produces confused and unprincipled judicial decisions. The sole objective test for reasonableness suggested by the formula is whether society as a whole would agree that the matter in question should be considered "private." 68 Empirically, this question may be difficult to answer. Courts must draw inferences from social practices, and they must assess the social functions served by specific privacy interests. ${ }^{69}$ From these general evaluations they must then determine where, in specific instances, to draw the line beyond which a warrant is required.

Two kinds of privacy interests are likely to be deemed "reasonable": those that are commonly asserted, and those that, though less frequently claimed, nevertheless play a significant role in the social

States $v$. Dionisio, 410 U.S. 1, 14 (1973) (subpoena of voicc exemplars by grand jury not a search within Fourth Amendment because "[n]o person can have a reasonable expectation that others will not know the sound of his voice"); Couch v. United States, 409 U.S. 322,336 n.19 (1973) (by surrendering tax records to accountant defendant relinquished "the necessary expectation of privacy to launch a valid Fourth Amendment claim").

67. Sce, e.g., United States v. Magana, 512 F.2d 1169, 1171 (9th Cir.), cert. denied, 423 U.S. 826 (1975) (expectation of privacy of an individual on his driveway "will generally depend upon the nature of [his activities] and the degree of visibility from the street"); United States v. Hanahan, 442 F.2d 649,653 (7th Cir. 197I) (expectation of privacy in garage depends on number of people with access to garage, presence or absence of windows, and proximity of garage to defendant's residence).

68. United States v. Solis, 536 F.2d 880, 881 (9th Cir. 1976) (question for Fourth Amendment protection is "the kind of intrusion a free society is willing to tolerate"); United States v. Savage, 482 F.2d 1371, $1372-73$ (9th Cir. 1973), cert. denied, 415 U.S. 932 (1974) ("what society recognizes as a reasonable expectation of privacy is restricted when the individual asserting the expectation is incarcerated"); United States v. Vilhotti, 323 F. Supp. 425, 431 (S.D.N.Y.), aff'd in part and rev'd in part on other grounds, 452 F.2d 1186 (2d Cir. 1971), cert. denied, 405 U.S. 1041 (1972) \& 406 U.S. 947 (1972) ("to ascertain what constitutes an unreasonable search the court must evaluate a person's efforts to insure the privacy of an area or activity in view of both contemporary norms of social conduct and the imperatives of a viable democratic society"); cf. United States v. Whitc, 401 U.S. 745, 751-52 (1971) (plurality opinion of White, J.) (quoted at note 66 supra). The relationship between reasonable expectations of privacy and societal norms is discussed in Kitch, supra note 48 , at $141-42,150-52$.

69. Justice Harlan himself later noted the significance of social values as a determinant of Fourth Amendment protection under his test:

The analysis must, in my view, transcend the search for subjective expectations or legal attribution of assumptions of risk. Our expectations, and the risks we assume, are in large part reflections of laws that translate into rules the customs and values of the past and present.

Since it is the task of the law to form and project, as well as mirror and reflect, we should not, as judges, merely recite the expectations and risks without examining the desirability of saddling them upon society.

United States v. White, 401 U.S. 745,786 (1971) (dissenting opinion). 
order. ${ }^{70}$ Both the prevalence and the importance of privacy interests, however, are inevitably matters of degree. Thus, the "reasonable expectation" standard compels courts to decide the degree of social solidarity or significance sufficient to raise a Fourth Amendment claim. For this decision the test applies no objective referent. Instead, courts tend to weigh particular privacy interests against other values, such as the need for effective law enforcement. ${ }^{i 1}$ The weights assigned to each competing value ultimately depend upon the judges' own principles and priorities. As the judges' own values vary, so does the scope of the Fourth Amendment.

By placing the Fourth Amendment on such an indefinite and relativistic foundation, the "reasonable expectation of privacy" test permits constriction of the Amendment's protections. Even where privacy has clearly been invaded, courts may be tempted to abandon the warrant requirement and to permit warrantless searches on the basis of ad hoc comparisons between the strength of the pertinent privacy interests and the needs of law enforcement. ${ }^{72}$ In striking such a balance, courts may view the reasonableness of the privacy claim

70. Telephone conversations provide a good example of a frequently exercised form of privacy. The lawyer-client privilege exemplifies a less common form of privacy, but one that is nonetheless regarded as highly important.

71. See, e.g., South Dakota v. Opperman, 428 U.S. 364, 377-78 (1976) (Powell, J., concurring) ("Resolution of this question requires a weighing of the governmental and societal interests advanced to justify such intrusion against the constitutionally protected interest of the individual citizen in the privacy of his effects.") The introduction of a balancing approach to Fourth Amendment values predates Katz. See Camara v. Municipal Court, 387 U.S. 523, 534-35 (1967); United States v. Rabinowitz, 339 U.S. 56, 65-66 (1950), overruled on olher grounds, Chimel v. California, 395 U.S. 752 (1969); Greenberg. The Balance of Interests Theory and the Fourth Amendment: A Selective Analysis of Supreme Court Action Since Camara and See, 6I CALIf. L. Rev. 1011, 1016 (1973).

What distinguishes balancing under the "reasonable expectation of privacy" formula from its pre-Katz antecedents is that the former may be employed to determine the scope of the Amendment as well as the degree of protection that it affords. Previous uses of balancing attempted to answer the more limited question whether, under certain circumstances, the needs of law enforcement justified relaxing probable cause and warrant requirements for matters undeniably within the Amendment's reach. That form of balancing continues, see pp. 1496-97 infra, but in addition courts may now consider the needs of law enforcement and other matters of social policy at the more fundamental level of determining whether a "search" or "scizure" within the meaning of the Fourth Amendment has occurred at all. See Kitch, supra note 48, at 139-40; Case Comment, Electronic Eavesdropping and the Right to Privacy, 52 B.U. L. REv. 831, $838-39$ (1972); The Supreme Court, 1967 Term, 82 HARv. L. REv. 93, 192-94 (1968).

72. Compare United States v. Montgomery, No. 75-1715, majority slip op. at 22 (D.C. Cir. May 26, 1977) (any decision finding wardantless search to be "an unlawful intrusion on privacy" invites complaint of "unreasonable interference with police officers who were only acting reasonably in coping with criminals") with id., dissenting slip op. at 6, 9-10 (enforcement of probable cause and reasonableness requirements by exclusion of evidence on "hypertechnicalities" debilitates law enforcement efforts) (Wilkey, J.). 
merely as an inverse function of the reasonableness of the search. ${ }^{73}$ Where a search is deemed reasonable, countervailing privacy values, even if commonly held or socially significant, may be considered insufficient to require strict adherence to constitutional protections. ${ }^{74}$

Furthermore, as Professor Amsterdam has noted, social "expectations" of privacy are subject to governmental manipulation. ${ }^{75} \mathrm{By}$ informing the public that warrantless searches would henceforth be the norm, the government could alter public perceptions of "reasonable" privacy interests and thereby remove almost any investigation from the reach of the Fourth Amendment. ${ }^{i 6}$ Thus, as Amsterdam observes, the "reasonable expectation of privacy" approach converts the Fourth Amendment into a social "Rorschach blot."77

Erosion of Fourth Amendment protections is particularly likely under the "reasonable expectation of privacy" approach because it balances an indeterminate personal value against a recognized governmental interest. An individual bears the burden of proving that his privacy expectations are "reasonable," that is, that they are recognized by society at large. ${ }^{78}$ But because privacy interests may be difficult to

73. The Supreme Court warned against this type of approach in Chimel v. California, 395 U.S. 752 (1969):

It is argued in the present case that it is "reasonable" to scarch a man's house when he is arrested in it. But that argument is founded on little more than a subjective view regarding the acceptability of certain sorts of police conduct, and not on considerations relerant to Fourth Amendment interests. Under such an unconfined analysis, Fourth Amendment protection ... would approach the evaporation point. Id. at 764-65.

74. See Note, Formalism, Legal Realism, and Constitutionally Protecled Privacy under the Fourth and Fifth Amendments, 90 HARv. L. REv. 945, 981 (1977) (noting that in recent cases, "the Court has declared some systematic searches . . . to be subject at most to ad hoc reasonableness scrutiny on the assumption that foresceable and 'minor' intrusions are unimportant and inoffensive to innocent people") (citations omitted).

75. Amsterdam, Perspectives on the Fourth Amendment, 58 MiNN. L. Rev. 349, 384 (1974).

76. Indeed, recently created exceptions to the warrant requirement suggest that certain expectations are being manipulated already. See South Dakota v. Opperman, 428 U.S. 364, 368-69 (1976) (warrantless inventory search of automobile upheld in part on grounds that public expects law enforcement officials to come into frequent contact with motor vehicles and that car owner had been placed on notice by street signs warning that autos might be towed); note 162 infra. But see United States r. Davis, 482 F.2d 893,905 n.30 (9th Cir. 1973) (court observed that a homeowner's right to Fourth Amendment protection of his home would not craporate merely because he was under mistaken supposition that government could enter when it pleased).

77. Amsterdam, supra note 75, at 375. See United States v. Johnson, 20 CRiM. L. REP. (BNA) 2367, 2369 (D.C. Cir. Jan. 12, 1977) (en banc) (Mackinnon, J., concurring) ("[T]he problem is not solved simply by invoking the [reasonable expectation of privacy] rule in Katz. That rule incorporates a fair amount of circularity. One will have a reasonable expectation of privacy over those areas that courts tell him he may reasonably expect to be private.")

78. See Note, A Man's Home Is His Fort, supra note 65, at 76-77. 
define $^{79}$ and are generally raised by those who stand convicted of crime, it is both easy and psychologically appealing to minimize the "costs" to society of permitting a warrantless search. Only the guilty appear to be affected, and an expectation of privacy for the purpose of concealing crime seems patently "unreasonable."so

The dangers inherent in the reasonable expectation of privacy standard are exemplified by judicial analysis of electronic tracking. Judges have approved warrantless electronic tracking in some cases on the grounds that the privacy interests affected by the beeper were relatively insignificant, that the beeper intrusions were justified by the needs of law enforcement, or that the criminal activities monitored were not subject to reasonable privacy expectations. ${ }^{81}$ Although Katz was formulated to accommodate the Fourth Amendment to technological development, the very novelty of beeper technology makes it difficult to determine what privacy interests society would recognize as "reasonable." Often courts rely on little more than their own value judgments to sustain the conclusion that electronic tracking either does or does not intrude upon "reasonable" expectations of privacy. ${ }^{\mathrm{s}}$ "

79. Benn, Privacy, Freedom and Respect for Persons, in PrIvacy 1, 1-4 (NOMOS XIII J. Pennock \& J. Chapman eds. 1971); Parker, A Definition of Privacy, 27 Rutcers L. REv. 275, 275-76 (1974); Shils, Privacy: Its Constitution and Vicissitudes, 31 LAw \& Contcup. Prob. 281, 281 (1966).

80. See, e.g., United States v. Turner, 528 F.2d 143, 159-60 (9th Cir.), cert. denied, 423 U.S. 996 (1975) (defendants challenging constitutionality of statutory wiretap could not complain of wiretap's intrusions beyond scope of legitimate police interest because they brought invasion on selves by mixing personal lives and criminal activities); United States v. Pui Kan Lam, 483 F.2d 1202, 1206 (2d Cir. 1973), cert. denied, 415 U.S. 984 (1974) (where appellants had gained entry to stranger's apartment by false representations and had made prior "suspicious" visits, electronic surveillance invaded no reasonable cxpectation of privacy: "Under the circumstances appellants may be held to have assumed that their activities might be monitored."); cf. Note, supra note 74 , at $980-85$ (balancing ap. proach to Fourth Amendment protections of privacy has led to relaxation of standards as result of "premium" placed by courts on effective law enforcement). But cf. Katz v. United States, 389 U.S. 347 , 360 (1967) (Douglas, J., concurring) (notes that Fourth Amendment protection cannot vary for different substantive offenses); United States v. Montgomery, No. 75-1715, majority slip op. at 22-23 (D.C. Cir. May 26, 1977) (dictum) (argument that government searches only criminals neglects fact that searches of innocent persons seldom litigated because charges never brought).

81. See, e.g., United States v. Hufford, 539 F.2d 32 (9th Cir.), cert. denied, 97 S. Ct. 533 (1976) (privacy interests insignificant); United States v. Frazicr, 538 I.2d 1322, 1325-26 (8th Cir. 1976), cert. denied, 97 S. Ct. 823 (1977) (Ross, J., concurring) (same); United States v. Holmes, 537 F.2d 227, 228-30 (5th Cir. 1976) (en banc; per curiam) (Ainsworth, J., dissenting) (privacy interests insignificant; intrusions justificd); United States $v$. French, 414 F. Supp. 800, 803-04 (W.D. Okla. 1976) (criminal activities not subject to reasonable expectation of privacy). Similar arguments were expressly rejected in United States v. Holmes, 521 F.2d 859, 865-66 (5th Cir. 1975), aff'd en banc by an equally divided court, 537 F.2d 227 (5th Cir. 1976) (affected privacy interests significant; law enforcement needs not compelling); and United States v. Bobisink, 415 F. Supp. 1334, 1340 (D. Mass. 1976) (affected privacy interests significant).

82. For examples of conclusory reasoning, see United States v. Holmes, 521 F.2d 859, 866 (5)th Cir. 1975), aff'd en banc by an equally divided court, 537 F.2d 227 (5th Cir. 
Moreover, the courts' value judgments themselves are in conflict, as each court has pegged the privacy values affected by the beeper at a different level on a sliding scale of Fourth Amendment protections. ${ }^{83}$

\section{Minimizing the Confusion: Some Limiting Principles in Katz}

To some extent, the confusion over the Fourth Amendment status of the beeper is unavoidable so long as privacy remains the central theoretical focus of Fourth Amendment analysis. ${ }^{8 t}$ Privacy, like most concepts of fundamental value, is a relative, indeterminate concept that is not easily converted into a workable legal standard. ${ }^{85}$ As Justice Stewart has observed, there is no "trick of logic" that will clarify Fourth Amendment privacy analysis. ${ }^{36}$ But a return to the standards articulated by the majority in Katz would alleviate the confusion and impose some structure on an otherwise amorphous "Rorschach blot."

Scrutiny of the majority opinion in Katz suggests two limiting principles that should guide Fourth Amendment privacy analysis. First, Katz implies that a privacy approach should not be employed where Fourth Amendment protection can be grounded in traditional property rights analysis. Second, where a property-oriented approach does not afford Fourth Amendment protection, Katz confines the scope of privacy analysis by concentrating on: (a) the means employed by the

1976) ("A person has a right to expect that when he drives his car into the street, the police will not attach an electronic surveillance device to his car in order to track him."); United States v. Bobisink, 415 F. Supp. 1334, 1339 (D. Mass. 1976) ("Surely a person's movements constitute an area where he should be able to have some expectation of privacy. ... [H]e can anticipate that he might be observed by someone following him. But it is something else entirely to have one's whereabouts monitored continuously by an undisclosed bug. [The beeper] goes far beyond any ordinary powers of observation about which citizens are reasonably put on notice."); United States v. French, 414 F. Supp. 800, 803-04 (W.D. Okla. 1976) ("What expectation of privacy was here infringeddid [the defendant] have a reasonable expectation that he could secret marijuana and not be observed? . . . Clearly viewed there is not implicated here any claimed right to maintain the privacy of one's personal movements and locations.")

83. See pp. 1464-65 supra.

84. To resolve the difficulties that he identifies in the reasonable expectation of privacy standard, Professor Amsterdam proposes what amounts to a departure from privacy analysis altogether. He suggests a new constitutional requirement that would permit searches only when conducted in compliance with legislative directives or judicially approved police regulations. This requirement would apply to all searches, including those excepted from warrant procedures. Professor Amsterdam argues that such a rule would relieve the pressure on the courts to create post hoc exceptions to the warrant requirement. Standard operating procedures would help law enforcement agencies to reduce the variability of their practices and at the same time would provide morc durable safeguards against unreasonable search and scizure activity. Amsterdam, supra note 75 , at $416-20$.

85. A. Millek, The Assault on Privacy 25 (1971). See Freund, Privacy: One Concept or Many, in Privicy, supra note 79, at 182, 183-84; note 79 supra (citing commentators). 86. Coolidge v. New Hampshire, 403 U.S. 443, 483 (1971) (plurality opinion of Stewart, J.). 
claimant to preserve his privacy, and (b) the effectiveness of those means in preserving the claimant's privacy vis-à-vis the public at large. ${ }^{87}$

\section{The Security of Private Property}

The first of these limiting principles has the character of a negative pregnant in the Katz majority opinion. The Court's refusal to be bound by the strict limitations of property rights analysis was not a disavowal of the important protections afforded by this traditional interpretation of the Fourth Amendment. The Court noted that the concept of a " "constitutionally protected area" " does not "necessarily" provide an adequate index of the Fourth Amendment's scope. ${ }^{s s}$ But the decision did not signal a retreat from the position adopted in Silverman $v$. United States ${ }^{89}$ that any physical intrusion on property protected in terms by the Fourth Amendment may constitute a search. ${ }^{90}$ Rather, Kalz recognized by reservation what the Court later reaffirmed in Alderman $v$. United States: ${ }^{91}$ the Fourth Amendment protects property as well as privacy. ${ }^{92} \mathrm{Katz}$ developed privacy analysis as a supplementary standard, to be used only where traditional property analysis proves inadequate..$^{93}$

87. In addition to the two limiting principles presented here, Justice Douglas insisted that another principle exists, which affords absolute protection against searches and seizures of certain objects, with or without a warrant. He included in this category personal papers and private written communications. Warden v. Hayden, 387 U.S. 294, 321 (1967) (Douglas, J., dissenting).

88. 389 U.S. 347,350 (1967).

89. 365 U.S. 505, 511-12 (1961) (warrantless electronic eavesdropping equipment making physical contact with heating duct in party wall violated Fourth Amendment).

90. Amsterdam, supra note 75, at 385. Cf. United States v. White, 401 U.S. 745, 756 (1971) (Douglas, J., dissenting) (argues for "strict construction" of Fourth Amendment with respect to constitutionally protected areas).

91. 394 U.S. 165 (1969).

92. Id. at $175,179-80$. As Judge Goldberg commented in United States v. Hunt, 505 F.2d 931 (5th Cir. 1974), cert. denied, 421 U.S. 975 (1975):

[A]lthough the right of privacy has been the major theme of modern Fourth Amendment jurisprudence, the property rights rationale cannot be ignored altogether. Perhaps it would not be too much to say that the continuing concern with property rights is prompted by the realization that an individual often has a very reasonable expectation of privacy in his private property, and that it is this expectation which the Fourth Amendment protects.

Id. at 937 (footnote omitted). See United States v. Johnson, 20 CRIM. L. ReP. (BNA) 2367, 2370 (D.C. Cir. Jan. 12, 1977) (en banc) (Bazelon, C.J., dissenting) (protection of private property against trespass forms "bedrock" of Fourth Amendment on which Kalz privacy concepts expand). But see United States v. Polk, 433 F.2d 644, 647 n.1 (5th Cir. 1970) (denial of absolute Fourth Amendment protection for property rights necessary so that reasonable expectation of privacy test may be "allowed its full scope").

93. Amsterdam, supra note 75, at 385. See 32 ALB. L. REv. 455, 460.61 (1968). Professor Weinreb suggests an approach that up to a point parallels the one proposed in this Note. He posits two varieties of privacy: privacy of place, which would inhere in 
Katz suggests that privacy analysis should replace the traditional property approach in two situations: where the government uses "nonphysical" methods of search ${ }^{94}$ and where the pertinent privacy interests themselves lack physical characteristics. In the case of a nonphysical search that penetrates the physical barriers of a constitutionally protected area, the scope of Fourth Amendment protection is defined by the area itself, ${ }^{95}$ and the privacy inquiry serves the narrow purpose of determining whether an invasion has in fact occurred. Katz stands for the proposition that under these circumstances an invasion of Fourth Amendment rights does not depend on the "presence or absence of a physical intrusion,"9g but occurs whenever the functional effect of the government's investigation is to gain access to matters otherwise protected. ${ }^{97}$

Where Fourth Amendment protection does not emanate from any tangible property interest, the scope of judicial inquiry broadens. It becomes necessary first to decide whether a cognizable privacy interest exists at all, and then to decide whether such an interest has been invaded. Only at this point does an analysis based on property rights become entirely inapposite. Thus, if the police had placed a bug on Katz's house ${ }^{98}$ or if they had seized written communications rather than oral ones, ${ }^{99}$ violation of physical privacy would have been obvious, and judicial search for a "reasonable expectation of privacy" would have been superfluous. But because evidence of such a physical

property, and privacy of presence. Although Professor Weinreb would thus distinguish property analysis from privacy analysis, he would continue to frame both in terms of personal "expectations." Weinreb, Generalities of the Fourth Amendment, 42 U. CHI. L. Rev. 47, 53.54 (1974). Such an approach would not eliminate the ambiguity present in the "reasonable expectation" standard.

94. Of course, even electronic surveillance uses "physical" means of detection in the sense that its operation is governed by principles of physical science. The term employed here is intended to signify invasions that work no physical alteration on their object, at least not one immediately perceptible to the senses.

95. See, e.g., Alderman v. United States, 394 U.S. 165, 176-77 (1969) (electronic surveillance of an individual's telephone violates Fourth Amendment protection of his home even if monitoring limited to conversations by third parties).

96. 389 U.S. at 353 .

97. This implication of Katz flows from the context of the decision itself. Had there been a clear physical invasion of property protected in terms by the Fourth Amendment, existing doctrine would have established a search, and there would have been no need to attempt a new rationale. Only because these elements were not present did it become clear that the presence or absence of a physical intrusion would not be determinative of the case before the Court. See pp. 1470-71 supra.

98. See, e.g., Alderman v. United States, 394 U.S. 165, 177-78 (1969) (dictum).

99. See, e.g., Ex parte Jackson, 96 U.S. 727, 733 (1878) (letters and sealed packages in the mail protected from warrantless search or seizure by Fourth Amendment). But see United States v. Ramsey, 45 U.S.L.W. 4577 (U.S. June 6, 1977) (international mail may be searched without warrant upon entry into United States). 
search and seizure was lacking the Court found it necessary to pursue its inquiry to a more subtle level.

By retaining explicit Fourth Amendment protection for property, this interpretation of Katz serves a useful purpose. The physical characteristics of property, apparent to both policeman and private citizen, confer on Fourth Amendment analysis a degree of specificity, clarity, and concreteness. A legislature would find it more difficult to manipulate property rights, and the Fourth Amendment rights defined by them, than to manipulate privacy expectations. These considerations argue for a Fourth Amendment analysis that looks to the prophylactic protections afforded to property in such cases as Silverman before invoking the more nebulous privacy concerns that resolved Katz.

\section{The Preservation of Privacy}

\section{a. A Focus on Means}

Where an analysis of privacy claims becomes necessary, Katz limits its scope to a focus on the means actually used by the claimant to protect his privacy, rather than on the claimant's intent or on the social acceptability of his claim. Instead of asking whether Katz expected his telephone conversation to be private and whether that expectation comported with social norms, the Katz Court inquired whether the petitioner had attempted to preserve his privacy, and answered this query by considering the steps he had taken to effect that purpose. Katz's choice of "what . . . to preserve as private" was treated by the Court as a matter for self-determination. ${ }^{100}$ His conversations were protected by the Fourth Amendment not because society values the privacy of telephone conversations, but because a person who enters a public booth and closes the door has adopted a means reasonably calculated to ensure that his particular conversations will not reach an "uninvited ear."101

This reading of $\mathrm{Katz}$ avoids the high level of abstraction inherent in the reasonable expectation of privacy test. Instead of looking to the general privacy interests of society as a whole, courts may concentrate

100. 389 U.S. at 351. Professor Amsterdam shares this interpretation of the decision. Amsterdam, supra note 75 , at 365 .

101. 389 U.S. at 352 . Although the Court referred to the "vital role" of the public telephone in private communication, $i d$., it treated this factor more as evidence that the petitioner had adopted means calculated to effect his purpose than as a test for the substantiality of his privacy interest. Social acceptance of the means of preserving privacy may be a useful index of the effectiveness of those means, but it must be carefully distinguished from social acceptance or disapproval of the purposes those means are cmployed to serve. See pp. $148 \mathrm{I}-82$ infra. 
on specific acts of an individual claimant. The Fourth Amendment issue becomes not whether particular privacy interests themselves are "prevalent" or "important," or whether, weighed against the needs of law enforcement, they "deserve" protection, but whether the steps an individual takes to preserve his privacy are reasonably calculated to achieve that purpose. ${ }^{102}$

A means-oriented analysis also permits an individual to secure as much or as little privacy as he desires by using means of obtaining privacy frequently or not at all, according to his own discretion. Society may not be prepared to recognize as reasonable the desire of a Howard Hughes to achieve near-total seclusion, because most people would neither expect nor desire so much privacy. But under the principles of $\mathrm{Katz}$, an eccentric recluse could protect his seclusion from warrantless governmental invasion so long as he sought to obtain his privacy by appropriate means.

\section{b. Privacy and the Public: The Reasonably Curious Person}

To determine whether a particular means of preserving privacy is reasonably calculated to achieve that purpose, Katz considers the effectiveness of the means in preventing intrusions by the public at large. ${ }^{103}$ In Katz the petitioner obviously failed to protect his conversations from governmental intrusion, but he adopted reasonable means for protecting them from the "uninvited ear" of the curious stranger. Because these conversations were private with respect to the public at large, they were protected by the Fourth Amendment against the government's "uninvited ear" as well. ${ }^{104}$ Whether the petitioner should have "expected" government surveillance was wholly irrele-

102. The emphasis on measures taken to preserve privacy has appeared in a number of decisions following $\mathrm{Katz}$, usually as a factor in determining whether the defendant exhibited a proper "expectation" of privacy. See United States v. Chadwick, 45 U.S.L.W. 4797,4800 (U.S. June 21, 1977) ("By placing personal effects inside a double-locked footlocker respondents manifested an expectation that the contents would remain free from public examination."); United States v. Wright, 149 F.2d 1355, 1364 (D.C. Cir. 1971), cert. denied, 405 U.S. 947 (1972) (leaving garage door ajar nine inches not a measure "calculated" to preserve interior from visual search); United States v. Haden, 397 F.2d 460, 465 (7th Cir. 1968), cert. denied, 396 U.S. 1027 (1970) ("One who intends a conversation or transaction to be private and takes reasonable steps to keep it private is protected from governmental intrusion ....") The emphasis on means has been used more to limit than to expand the scope of Fourth Amendment protection. See Note, A Man's Home Is His Fort, supra note 65 , at 70-72, 75-77.

103. A similar interpretation was suggested in Comment, Police Helicopter Surveillance and Other Aided Observations: The Shrinking Reasonable Expectation of Privacy, 11 CAL. W.L. REV. 505, 515, 523-24 (1975).

104. P. 1471 supra. 
vant. ${ }^{105}$ The only "risk" of exposure that the Court regarded as significant in terms of Fourth Amendment protection was that members of the public might overhear what was being said. Once this risk was eliminated by shutting the door of the booth, the petitioner was protected by the Constitution from additional actions the police might take to discover his activities.

The Court's emphasis on means and on their effectiveness in securing privacy from the public at large leads to a workable standard for determining Fourth Amendment protection. The government must stand in the shoes of the public: it may see, know, and take without a warrant only what members of the public may see, know, and take. So long as an individual has protected his privacy against intrusion by his fellow citizens, he may assume that he has also protected it against governmental interference. Thus, his reliance on Fourth Amendment protection is "justifiable" where the means he has employed to preserve his privacy are calculated to be effective against reasonably curious members of the public at large.

Although the concept of the "reasonably curious person" may not be defined with precision, its basic features may be sketched. A reasonably curious person is, first, an individual with normal motives for inquiring into others' affairs. He (or she) is neither a voyeur nor a member of a class with unusually strong incentives for investigation (such as business competitors or newspaper reporters). Second, a reasonably curious person seeks to satisfy his curiosity by employing means of discovery that other members of the public with similar motives would be likely, as an empirical matter, to use. Such an individual neither resorts to illegal methods nor uses means that, although legal, are uncommon. Finally, the reasonably curious person may be purposeful in his investigation, but only to the extent that normal curiosity impels.

Defining Fourth Amendment protection in terms of the reasonably curious person clarifies what the Court meant in Katz when it said that "[w] hat a person knowingly exposes to the public" is not subject to Fourth Amendment protection, but "what he seeks to preserve as private .. may be constitutionally protected." 100 To determine whether a governmental investigation has intruded on Fourth Amend-

105. Indeed, had it considered the issue, the Court might very well have concluded that such an expectation was reasonable, given the criminal nature of the petitioner's activities. See Amsterdam, supra note 75, at 384 ("An actual, subjective expectation of privacy obviously has no place in a statement of what Kalz held or in a theory of what the fourth amendment protects.")

106. 389 U.S. at $351-52$ (emphasis supplied). 
ment rights, courts should inquire whether the fruits of the search were matters that a reasonably curious person, using the ordinary means of investigation at his disposal, might have discovered. Under this test, items or information actively and "knowingly" exposed to others do not receive constitutional protection, at least to the extent of the exposure, since by definition such matters have been rendered accessible to the public. ${ }^{107}$ Likewise, when an individual makes no effort to preserve something as private, so that any reasonably curious member of the public may have access to it, then government agents may obtain that same information without conducting a search. Even if an individual attempts to preserve something as private, but does so by means not reasonably calculated to achieve his purpose, his negligent exposure of the matter in question defeats any claim to constitutional protection. ${ }^{108}$ But if the means he chooses are designed

107. In Lnited States v. White, 401 U.S. 745 (1971), the Court upheld electronic surveillance by use of a bugged informant, concluding that the electronic device only picked up what was knowingly disclosed to the informant and therefore did not invade a privacy interest protected by the Fourth Amendment. This decision, however, explicitly rests on the fact that one party to the conversations, the informant, participated in the surveillance. Id. at 749 (plurality opinion of White, J.). Justice White, writing for four members of the Court, emphasized that the same information could have been obtained by having the informant write out transcripts or reports after each conversation. Id. at 751 .

This aspect of the Court's decision is consistent with the interpretation of Kalz proposed in this Note, because there was in fact disclosure to another member of the public, who in turn conveyed the same information to the police. In Katz it was of course possible that the other parties to the petitioner's conversations might have revealed them to the government, but the White Court implied that only actual consent could have justified the Katz bugging. See id. at 749 (distinguishing Kalz); cf. Mancusi v. DeFortc, 392 U.S. $364,369-70$ (1968) (dictum) (fellow union officials might have given valid consent to search of defendant's sharcd office but no such consent is claimed).

According to the standards proposed in this Note, however, the Court's decision in White may be incorrect on another ground. Some of the monitored conversations took place in the defendant's home and automobile by means of a bugging device concealed on the person of the informant, who had been invited in as a guest. 401 U.S. at 747. It is arguable that, although the informant could consent to disclosure of the conversations that the defendant had shared with him, he could not validly consent to physical intrusion of the bug onto the defendant's private property. See Weinreb, supra note 93, at 69; p. 1485 infra; cf. Gouled v. United States, 255 U.S. 298, 305-06 (1921) (government agent gaining entry as guest to defendant's home may not use invitation as occasion for warrantless search). See generally Greenawalt, The Consent Problem in Wiretapping \& Eavesdropping: Surreptitious Monitoring wilh the Consent of a Parlicipant in a Conversation, 68 Colum. L. Rev. 189 (1968) (arguing on the basis of functional privacy considerations for a result contrary to that subsequently reached in White); Case Comment, supra note 71 , at 841.47 (criticizing White).

108. Several courts have held that carelessness or inaction in protecting privacy is sufficient to defeat a Fourth Amendment claim. See, e.g., United States v: Wilson, 472 F.2d 901 (9th Cir. 1972), cert. denied, 414 U.S. 868 (1973) (no expectation of privacy when door of apartment left open); United States v. Fuller, 441 F.2d 755, 761 (4th Cir.), cert. denied, 404 U.S. 830 (1971) (dictum) (eavesdropping on conversations in public permissible if accomplished without electronic amplification). In some cases courts have characterized careless exposure as "knowing exposure." Ponce v. Craven, 409 F.2d 621, 625 (9th Cir. 
to have the desired effect of protecting privacy against the public at large, then those means are sufficient to raise constitutional protection against governmental intrusion as well. ${ }^{109}$

This interpretation of Katz does not insist that government investigators employ only those technologies that a reasonably curious person might employ. But it does insist that the government, whether its technology be simple or sophisticated, performs a Fourth Amendment search whenever its investigation achieves results that a reasonably curious person could not achieve. Because the government may intrude only to the extent that reasonably curious persons might intrude, it cannot by unilateral action alter the scope of an individual's "justifiable reliance" on his privacy. That reliance depends solely upon what other citizens might do, and upon the means the individual adopts to protect his affairs from public notice. ${ }^{110}$

This approach does not eliminate the flexibility of Fourth Amendment jurisprudence. It requires courts to make empirical judgments concerning the nature of the reasonably curious person and the effectiveness of means used to preserve privacy. These judgments, in turn, allow some latitude in fixing the scope of Fourth Amendment protection. But the degree of variability is more limited than that under the reasonable expectation of privacy standard, because the judgments required by the proposed approach concern conduct rather than expectations and values. Courts are called upon to measure the conduct of the reasonably curious person against the conduct of persons attempting to preserve their privacy. The circumstances of each case bear more directly on these considerations than they do on determinations of the privacy that society as a whole recognizes as reasonable. The result is a more reliable and consistent standard for defining Fourth Amendment protections than has been possible under Justice Harlan's formula.

1969) (Fourth Amendment rights not violated when police looked through partly open bathroom window); United States v. Llanes, 398 F.2d 880, 884 (2d Cir. 1968), cert. denied, 393 U.S. 1032 (1969) ("conversations carricd on in a tone of voice quite audible to a person standing [in public hallway outside apartmcnt]" are not protected by Fourth Amendment). See generally Note, A Man's Home Is His Fort, supra note 65, at 69-70 (citing cases).

109. Professor Amsterdam argues that the Fourth Amendment fails in its central purpose if it requires individuals to protect their privacy by such stringent means that they are prevented from leading normal lives. Amsterdam, supra note 75 , at 402 . One commentator suggests that subsequent application of the reasonable expectation standard has led to just that result. Note, A Man's Home 1 s His Fort, supra note 65, at 70-72. The interpretation of $\mathrm{Kalz}$ proposed in this Note responds to Professor Amsterdam's admonition by placing police on an equal footing with the public at large. Privacy in one's everyday affairs becomes the touchstone for privacy against warrantless governmental intrusion.

110. Comment, supra note 103 , at $515,524$. 


\section{Katz in the Context of Beepers}

\section{A. Intrusion by Physical Presence}

Recognizing the limitations on privacy analysis set by this interpretation of Katz facilitates understanding of the beeper's search and seizure implications. In most situations, resort to privacy analysis should be unnecessary, because placement of the beeper represents a physical invasion of the security guaranteed to private property by the Fourth Amendment. The beeper's physical invasion is unique. It converts private property to a use-surveillance-unintended by the original owner. ${ }^{111}$ Because the beeper serves as a surrogate police "presence," not only does its initial attachment involve an "actual trespass," 112 but its continuing placement works a continuing violation of Fourth Amendment rights. ${ }^{113}$ Like an electronic voice monitor, the beeper may thus offend the Fourth Amendment even when attached to an exterior surface. ${ }^{114}$

The clearest case of physical intrusion arises when the beeper is attached without consent to property protected as an "effect" by the Fourth Amendment. In such a case a search occurs at the moment of contact. A search may also occur when a property owner consents to the initial attachment but the property is subsequently transferred to another individual whose movements the police wish to track. ${ }^{115}$ Once the property comes into the new owner's possession, the original owner's consent is no longer effective, and the beeper's continuing presence on the property violates the Fourth Amendment. ${ }^{116}$ Finally,

111. Of course, the beeper does not physically detain or damage the property, but it does convert it into a kind of "informant." See United States v. Holmes, 521 F.2d 859, 865 n.11 (5th Cir. 1975), aff'd en banc by an equally divided court, 537 F.2d 227 (5th Cir. 1976) (finding "slight if any difference" between attached beeper and agent hidden in trunk who tracks location of vehicle).

112. United States v. Holmes, 521 F.2d 859, 865 (5th Cir. 1975), aff'd en banc by an equally divided court, 537 F.2d 227 (5th Cir. 1976); see id. at 865 n.11, 866, 868 (suggesting analogies between attached beeper and police presence).

113. See Berger v. New York, 388 U.S. 41, 59 (1967) (prolonged period of electronic surveillance is "equivalent of a series of intrusions, searches, and scizures").

114. Compare Silverman v. United States, 365 U.S. 505, 512 (1961) (use of "spike mike" making contact with heating duct in defendant's building is an "actual intrusion" for Fourth Amendment purposes) with United States v. Holmes, 521 F.2d 859, 865 (5th Cir. 1975), aff'd en banc by an equally divided court, 537 F.2d 227 (5th Cir. 1976).

115. E.g., United States v. Hufford, 539 F.2d 32 (9th Cir.), cert. denied, 97 S. Ct. 533 (1976) (beeper attached to drum of caffeine prior to delivery to (lefendant purchaser); United States v. Perez, 526 F.2d 859 (5th Cir.), cert. denied, 429 U.S. 846 (1976) (beeper attached to television set transferred to defendants as part of illegal sale of heroin).

116. For consent to be effective, it is well established that a third party must either have a right to "mutual use of the property" amounting to "joint access or control for most purposes," United States v. Matlock, 415 U.S. 164, 171 n.7 (1974), or else a direct grant of authority to make the consent, Stoner v. California, 376 U.S. 483, 488-90 (1964). 
even if attachment of the beeper is legally justified, a physical intrusion may occur when the item to which the beeper is attached is taken onto real or personal private property. Again, the beeper interferes with the security of the property on which it finally rests. Because it goes where a law enforcement officer cannot go without violating the Fourth Amendment, the beeper's location within a constitutionally protected area results in a search. ${ }^{117}$

At least one court has attempted to minimize the significance of the beeper's continuing presence by asserting that police are responsible only for the initial attachment of a beeper, and that subsequent intrusions created by the beeper's physical presence are of an inadvertent character insufficient to create a Fourth Amendment claim. ${ }^{118}$ Yet the police who install a beeper expect it to remain in place and to follow the item to which it is attached wherever the item goes. Consequently, police are as responsible for subsequent intrusions as they are for the original attachment. ${ }^{119}$

Legal ownership alone is insufficient where actual control has been surrendered. See id.; Chapman v. United States, 365 U.S. 610, 616-17 (1961). In cases such as United States v. Hufford, 539 F.2d 32 (9th Cir.), cert. denied, 97 S. Ct. 533 (1976), and United States v. Bobisink, 415 F. Supp. 1334, 1338 n.5 (D. Mass. 1976), drug manufacturers lacked the capacity to consent to the placement of beepers on property after it had been transferred to the defendant purchasers, since at that point the manufacturers maintained neither mutual control nor rights of ownership. Indeed, in Hufford consent may have been ineffective prior to transfer even though the company had control of the drum, because the attachment occurred subsequent to payment of a deposit by one defendant, and the company lacked both actual and implied authority to waive his constitutional rights. See United States v. Martyniuk, 395 F. Supp. 42, 43 (D. Ore. 1975), aff'd in part and rev'd in part sub nom. United States v. Hufford, 539 F.2d 32 (9th Cir.), cert. denied, $97 \mathrm{~S}$. Ct. 533 (1976).

117. See United States v. Holmes, 521 F.2d 859, 865 (5th Cir. 1975), aff'l en banc by an equally divided court, 537 F.2d 227 (5th Cir. 1976).

118. United States v. French, 414 F. Supp. 800, 803 (W.D. Okla. 1976). A similar conclusion appears to have been assumed in United States v. Emery, 541 F.2d 887, 889-90 (lst Cir. 1976), and United States v. Perez, 526 F.2d 859, 863 (5th Cir.), cert. denied, 429 U.S. 846 (1976), where the courts considered only whether the initial attachmont required a warrant.

119. The contention that police are not responsible for post-attachment intrusions seems to rest in part on notions of assumption of risk. Those engaged in criminal activity, it is urged, assume greater risks of surveillance than the average person; in this sense, persons who deal in contraband or controlled substances bring governmental intrusions upon themselves. See United States v. Perez, 526 F.2d 859, 863 (5th Cir.), cert. denied, 429 U.S. 846 (1976); United States v. French, 414 F. Supp. 800, 804 (W.D. Okla. 1976).

Application of assumption of risk principles to Fourth Amendment adjudication may be inappropriate even under the reasonable expectation of privacy standard, as Justice Harlan himself obscrved. United States v. Whitc, 401 U.S. 745, 786 (1971) (Harlan, J., dissenting). To the extent such an approach is grounded in the Katz majority opinion it is no more tenable, for it must rest on a distorted concept of "knowing exposure." This approach views those engaged in criminal activity as chargeable with the knowledge that their affairs are likely to become the object of secret government surveillance. But this distorts the meaning of the knowing exposure concept, which emphasizes aclual exposure to the public. See pp. 1482-83 \& note 107 supra. Because electronic tracking must be secret to be effective, "exposure" to a beeper taken onto private property must be 
Because the beeper is small, because it does no apparent damage to property, and because attachment does not wrest the property from the owner or impede use in any apparent way, some courts have asserted that attachment, at least to a vehicle, is a "technical trespass" too insignificant to require stringent Fourth Amendment restrictions. ${ }^{120}$ This assertion rests on the contention, drawn from Cardwell $v$. Lewis, ${ }^{121}$ that a beeper attached to an external surface exposed to public contact does not invade any reasonable expectation of privacy. ${ }^{122}$ In Cardwell v. Lewis the Supreme Court upheld a warrantless seizure of paint scrapings and tire castings from an automobile. Justice Blackmun's plurality opinion argued that an automobile is subject to "lesser" expectations of privacy than a dwelling because of its mobility, its inability to escape public scrutiny, and its relatively rare use as a repository for personal effects. For these reasons, the plurality treated the physical intrusion involved in the case as de minimis and hence not protected. ${ }^{123}$

unknowing. Nor may the suspects be charged with "negligent" exposure in such a case, since beeper intrusions would probably not be made by reasonably curious members of the public. See pp. 1481-8t supra. The suspects would be "rightfully oblivious to the risk" that their property might be invaded by a bug. Holmes v. Burr, 486 F.2d 55, 72 (9th Cir.), cert, denied, 414 U.S. 1116 (1973) (Hufstedler, J., dissenting).

120. E.g., United States v. Hufford, 539 F.2d 32, 34 (9th Cir.), cert. denied, 97 S. Ct. 533 (1976) (attachment of beeper and presence on truck an intrusion inferior to entering prisate garage or opening trunk hood); cf. United States v. Polk, 433 F.2d 644, 647-48 (5th Cir. 1970) (nonelectronic intrusions required for vehicle identification, though involving a "technical trespass," are "outside any reasonable expectations of privacy"). But see United States v. Bobisink, 415 F. Supp. 1334, 1335-36, 1338 (D. Mass. 1976) (rejecting Government argument that beeper intrusion "does not come up to the level of a 'search" ").

121. 417 U.S. 583 (1974).

122. Several beeper cases cite Cardwell $v$. Lewis in reaching the conclusion that becpers are a minimal intrusion. See, e.g., United States v. Hufford, 539 F.2d 32, 34 (9th Cir.), cert. denied, 97 S. Ct. 533 (1976) (due to lesser expectation of privacy in vehicles, attachment and monitoring of beeper not within Fourth Amendment); United States v. Frazier, 538 F.2d 1322, 1326 (8th Cir. 1976), cert. denied, 97 S. Ct. 823 (1977) (Ross, J., concurring) (the intrusion caused by a beeper, "if any can be said to exist, [is] decidedly abstract and theoretical"); United States v. Hoimes, 537 F.2d 227, 229 (5th Cir, 1976) (en banc; per curiam) (Ainsworth, J., dissenting) (installation of beeper "only a minimal intrusion"). But see United States v. Holmes, 521 F.2d 859, 864-65 (5th Cir. 1975), aff'd en bane by an equally divided court, 537 F.2d 227 (5th Cir. 1976).

123. 417 U.S. at 590-91. The Court's decision in Cardwell $v$. Lewis actually rested on an interpretation of the automobile exception to the Fourth Amendment warrant requirement. See p. 1500 \& note 171 infra. Four Justices agreed that individuals' low expectation of privacy in automobiles creates a distinction between mobile rehicles and other effects, see Chambers v. Maroney, 399 U.S. 42,48 (1970), rendering warrantless searches or seizures of vehicles permissible where warrantless searches or seizures of more protected items would not be. 417 U.S. at $590-92$ (plurality opinion of Blackmun, J.). Their rationale was thus predicated on the insignificance of the privacy interests involved as well as on the insignificance of the intrusion. Justice Powell's deciding vote was cast on the separate ground of his objection to habeas corpus relief where the petitioner had an opportunity to litigate fully his Fourth Amendment claims in state court. $1 d$. at 596 (Powell, J, concurring in the result). 
Regardless of the merits of this theory in its own context, ${ }^{124}$ it should not be extended to beepers. Attachment of a beeper is far from a minimal intrusion. Searches permitted as minimal intrusions have ordinarily involved brief physical examinations similar to those that might arguably be expected from the public at large. ${ }^{125}$ By contrast, an attached beeper represents a lengthy physical intrusion that appropriates an item for an unintended use. ${ }^{126} \mathrm{~A}$ reasonably curious person might peer into the windows of an automobile, inspect its tires, or even look under its hood. ${ }^{12 \pi}$ No reasonably curious person, however, would attach a beeper to another person's car. Therefore, a car owner need not act to protect his privacy against such an event. ${ }^{128}$

124. Cardwell $v$. Lewis has been criticized by several commentators. See, e.g., Note, Confusing the Confusion: Automobile Search and Seizure Takes a New Turn, 12 Hous. L. REv. 460, 467-68 (1975) (noting difficulties of determining what parts of an automobile are sufficiently "exterior" that they may be searched with impunity); Comment, Irarrantless Searches and Seizures of Automobiles and the Supreme Court From Carroll to Cardwell: Inconsistently Through the Seamless W'eb, 53 N.C. L. REv. 722, 742-47 (1975); cf. Weinreb, supra note 93 , at $75-76$ (noting that contrary to assumption of automobile exception, rehicles often serve as private repositories). The commentary has not altered the Court's view. See South Dakota v. Opperman, 428 U.S. 364, 368 (1976) (quoting Cardwell v. Lewiss "lesser expectation" rationale with apparent approval).

125. See United States r. Brignoni-Ponce, 422 U.S. 873, 880 (1975) (intrusion from border patrol roving checkpoint characterized as "limited" and "modest," lasting no more than a minute); United States v. Sherriff, 546 F.2d 604, 607 (5th Cir. 1977) (close visual examination of vehicles parked in private area open to the public does not invade reasonable expectation of privacy); United States ex rel. Stanbridge v. Zelker, 514 F.2d 45, 52 (2d Cir.), cert. denied, 423 U.S. 872 (1975) (photographing portion of auto's interior in plain view involved some intrusion but no Fourth Amendment violation); United States v. Polk, 433 F.2d 644, 646-48 (5th Cir. 1970) (narrowly circumscribed auto inspection to determine vehicle identification number involved no more intrusion than that to be normally expected from the public); United States v: Johnson, 431 F.2d 441, 441 (5th Cir. 1970) (en banc; per curiam) (alternative holdings) (vehicle identification check either not a search or else reasonable under the circumstances; intrusion "did not violate the right of the people to be secure in their persons, houses, papers or effects").

126. See United States v. Holmes, 521 F.2d 859, 865 (5th Cir. 1975), aff'd en bane by an equally divided court, $537 \mathrm{~F} .2 \mathrm{~d} 227$ (5th Cir. 1976) (contrasting attachment of beeper with permissible intrusions of "limited scope, purpose and duration"); United States v. Bobisink, 415 F. Supp. 1334, 1339 (D. Mass. 1976) (installation of beeper not a minimal intrusion because it involves "actual trespass" into areas "under the umbrella of the Fourth Amendment" and carries potential for significant invasions of privacy); cf. Note, The Concept of Privacy and the Fourth Amendment, 6 U. MICH. J. L. REF. 154, 182 (1972) ("entry of . . material objects under government control" such as bugging devices are an offensive presence even apart from information-gathering activities).

127. See United States v. Polk, 433 F.2d 644, 647 (5th Cir. 1970) (inspection of vehicle identification numbers under hood, on doorpost, or on frame of automobile involves only intrusions into parts of automobile often in "plain riew" of "casual or purposeful onlookers").

128. See United States v. Holmes, 521 F.2d 859, 864-65 (5th Cir. 1975), aff'd en banc by an equally divided court, 537 F.2d 227 (5th Cir. 1976); 29 VaND. L. Rev. 514, 519-26 (1976). The Holmes court also noted that it is difficult, if not impossible, to protect one's property against beepers. "[O]nce one leaves home and enters the public streets," there is "no way to lock a door or place the car under a protective cloak as a signal to the police that one considers the car private." 521 F.2d at 865 . Cf. United States v. Portillo- 
Every reported case dealing with the Fourth Amendment implications of electronic tracking could have been decided by use of property analysis. Beepers have, without consent, been either attached to private property or taken onto private property. Despite the courts' frequently contrary conclusions, the beeper's physical presence almost invariably violated Fourth Amendment rights. In three cases the police did obtain consent from third parties before attaching the beeper. In two of these, however, the consents became ineffective when the property to which the beepers were attached was transferred to the suspects' exclusive control. ${ }^{129}$ In only one case did the original consenting party retain an interest in the property sufficient to justify the beeper's continuing presence. ${ }^{130}$ The cases in which beepers were attached to contraband raise more difficult questions about the beepers' infringement of Fourth Amendment interests in the bugged objects. ${ }^{131}$ In

Reyes, 529 F.2d 844, 848 (9th Cir. 1975), cert. denied, 97 S. Ct. 267 (1976) (insertion of key into automobile door to check whether it fit was not minimal intrusion but "beginning of the search").

129. United States v. Hufford, 539 F.2d 32 (9th Cir.), cert. denied, 97 S. Ct. 533 (1976); United States v. Bobisink, 415 F. Supp. 1334 (D. Mass. 1976). See also People v. Smith, 136 Cal. Rptr. 764 (Ct. App. 1977) (holding consent by rental agent ineffective for attachment of beeper to rented airplane).

130. In United States v. Abel, 548 F.2d 591 (5th Cir. 1977), cert. denied, 45 U.S.L.W. 3788 (U.S. June 6,1977 ), an airplane was subject to joint ownership or control, so consent for attachment of the beeper by either owner was effective. Id. at 592.

131. The degree to which contraband is protected by the Fourth Amendment is a matter of some doubt. Following the analysis employed in this Note, this question must be divided into two subsidiary issues: whether contraband may be an "effect" under the Fourth Amendment and thus protected against physical intrusions, and whether it may be secluded so that the privacy of its location and movement is preserved. For a discussion of the latter issue, see note 147 infra.

Although searches for contraband were one of the chicf pre-Revolutionary abuses of search and seizure that the Framers endeavored to correct, Kaplan, Search and Seizure: A No-Man's Land in the Criminal Law, 49 CALIF. L. Rev. 474, 475-76 (1961), the property status of contraband under the Fourth Amendment has never been definitively determined. In United States v. Jeffers, 342 U.S. 48, 53 (1951), the Court held that a federal statute banning "property rights" in narcotics did not affect the possessor's Fourth Amendment rights to protection from warrantless search and seizure. This holding, however, is limited by the facts of the case: it involved a warrantless search of private quarters in which the contraband had been secluded and to which the defendant was a frequent invitee. Thus, the Court's decision stands mainly for the proposition that governmental interest in contraband does not reduce or eliminate property or privacy interests independently protected by the Fourth Amendment. See United States v. Lisk, 522 F.2d 228, 232 (7th Cir. 1975), cert. denied, 423 U.S. 1078 (1976) (opinion of Stevens, $\mathrm{J}$., on petition for rehearing) (interpreting Jeffers as holding that a seizure of contraband violates Fourth Amendment rights if the claimant has property rights in the place being searched or if the search is directed at him); cf. United States v. Connolly, 479 F.2d 930, 936 (9th Cir.), cert. dismissed, 414 U.S. 897 (1973) (warrantless search of defendant's premises violated Fourth Amendment although police had reason to believe that contraband was stored on property).

The courts in some beeper cases have indicated that the contraband by itself is denied any Fourth Amendment protection from physical intrusion. See United States v. Emery, 541 F.2d 887, 889.90 (1st Cir. 1976); United States v. French, 414 F. Supp. 800, 803 (W.D. 
those cases, however, the beepers were subsequently taken onto private property. ${ }^{132}$ The result was physical intrusion into a place to which Fourth Amendment protections extend. Thus, in nearly every decided beeper case, traditional property rights analysis should have led the court to hold that the beeper's attachment was a physical invasion resulting in a search and seizure within the meaning of the Fourth Amendment.

\section{B. Intrusion by Monitoring}

Only rarely should it be necessary to pursue analysis of search and seizure questions raised by the beeper beyond the level of physical intrusions. Nevertheless, there may be cases where property interests fail to afford protection against surveillance by means of electronic tracking devices. For the present, this problem is likely to arise primarily in cases where defendants lack standing to object to the beeper's

Okla. 1976). Support for this position may be inferred from Wrarden v. Hayden, 387 U.S. 294, 299-300, 306-07 \& n.l1 (1967), which, in the process of climinating the "merc evidence" rule, stated that contraband may be seized without a warrant when encountered during the course of an otherwise legal search. The support is ambiguous, however, for under the circumstances this result was fully consistent with the exigency and plain view exceptions to the warrant requirement, see pp. 1496-97 \& note 161 infra. Moreover, that the Court also permitted warrantless seizure of lawfully possessed effects supplying evidence of crime signifies that its rationale did not depend on the property status of the item seized. 387 U.S. at 306-07.

Precedent thus fails to resolve the issue of Fourth Amendment protection of contraband. It should be noted, however, that excluding contraband from the class of effects protected from physical intrusion by the Fourth Amendment would involve a significant departure from the established proposition that actual use and possession rather than legal ownership form the source of Fourth Amendment rights. See, e.g., Jones v. United States, 362 U.S. 257, 267 (1960) (anyone legitimately on premises may challenge legality of search if its fruits are introduced against him). Such a departure should at the very least be strictly limited to circumstances where possession of the contraband itself constitutes a crime. The assumption in United States v. Pcrez, 526 F.2d 859 (5th Cir.), cert. denied, 429 U.S. 846 (1976), that goods obtained by illegal means, but otherwise perfectly innocent in character, are also stripped of property protections afforded by the Fourth Amendment ignores a tenet of the criminal justice system. It permits the police, rather than the courts, to determine in the first instance what is and is not illegal, and to act on that judgment by interfering with individual rights.

Where the item is presumptively of criminal character a warrant requirement for attachment of beepers to the contraband is unlikely to impose undue burdens on law enforcement. To attach the beeper, contraband must at some point come into the possession of the police. When that occurs, there is unlikely to be any difficulty delaying release of the contraband until a warrant for the beeper can be obtained. Indeed, if such a delay were for some reason impossible, police would have a valid excuse for dispensing with the warrant on grounds of "exigent circumstances." See pp. 1500-02 infra.

132. United States v. Emery, 541 F.2d 887 (lst Cir. 1976) (apartment); United States v. Perez, 526 F.2d 859 (5th Cir.), cert. denied, 429 U.S. 846 (1976) (property placed in private automobile); United States v. French, 414 F. Supp. 800 (W.D. Okla. 1976) (barn). 
attachment and physical presence. ${ }^{133}$ For example, a passenger in another person's automobile might lack standing to object to a beeper's physical presence, as might a guest or bailee if the property owner consented to attachment. ${ }^{13 *}$ Moreover, the history of electronic eavesdropping demonstrates the danger of resting protection entirely on the notion of physical intrusion on private property. ${ }^{135} \mathrm{New}$ technological developments may obviate the need for physical attachment of a monitoring device, ${ }^{136}$ making privacy rights a primary rather than supplementary source of Fourth Amendment protection.

Where the physical presence of a beeper does not cause a physical invasion proscribed by the Fourth Amendment, monitoring the beeper's location and movement impermissibly intrudes on privacy only if it conveys information that is not accessible to reasonably curious members of the public. ${ }^{137}$ If the beeper permits police to

133. To determine whether a search or seizure has occurred, it is sufficient to consider whether use of the beeper violated someone's Fourth Amendment rights. Standing goes to the narrower question of whether the search violated a particular defendant's rights, so that evidence obtained as a "fruit" of the search cannot be introduced against him at trial. See generally Trager \& Lobenfeld, The Law of Standing Under the Fourth Amendment, 41 BrookLyN L. Rev. 421 (1975). The standing issues raised by use of the beeper lie beyond the focus of this Note. The purpose of mentioning standing at this juncture is simply to point up the need for privacy analysis in situations where no property interest of the defendant is affected by the beeper's physical intrusion.

134. See United States v. Abel, 548 F.2d 591, 592 (5th Cir. 1977), cert. denied, 45 U.S.L.W. 3788 (U.S. June 6, 1977); United States v. Holmes, 521 F.2d 859, 862 (5th Cir. 1975), aff'd en banc by an equally divided court, 537 F.2d 227 (5th Cir. 1976).

135. See Silverman v. United States, 365 U.S. 505, 512-13 (1961) (Douglas, J., concurring) (arguing that trespass doctrine rendered obsolete by technological advances that allow bugging of person's premises without physical penetration).

136. Infrared cameras alrcady enable investigators to detect the presence of persons or objects concealed behind physical enclosures. Scintillators permit detection of certain objects. See Corngold v. United States, 367 F.2d 1, 2-3 (9th Cir. 1966) (en banc) (upholding on basis of pre-Katz trespass doctrine use of scintillator in public hallway to detect radioactive matter in defendant's apartment).

137. The threshold question of what it is the beeper tracks has provoked some conflict. Two positions have emerged. One treats electronic tracking as a " probing, exploratory quest for evidence of crime" "that amounts to a search whenever it provides the government with information otherwise private. United States v. Holmes, 52l F.2d 859, 866 (5th Cir. 1975), aff'd en banc by an equally divided court, 537 F.2d 227 (5th Cir. 1976) (quoting Marshall v. United States, 422 F.2d 185, 189 (5th Cir. 1970)). See United States v. Bobisink, 415 F. Supp. 1334, $1337-40$ (D. Mass. 1976). A second position, implicit in United States v. French, 414 F. Supp. 800, 803-04 (W.D. Okla. 1976), is that the extent of a search is determined by the government's purpose. In this view, if the government's aim is only to track the movements of property, then information from the same tracking operation concerning movements of persons comes into the government's hands only incidentally and is irrelevant to Fourth Amendment issues. To the extent that this latter view rests on an assessment of governmental intent, it conflicts with Katz, which defines Fourth Amendment search and seizure in terms of actual invasions of an individual's privacy, and not in terms of those "invasions" that serve the government's purpose. 389 U.S. at 353 . "[T] he essence of a search is the gathering of nonpublic in- 
"see" only what reasonably curious persons might see, it reveals only information that has been knowingly or carelessly exposed to the public. Such information is subject to search without a warrant by any method that is otherwise legal.

The problem with electronic tracking, however, is that the purview of the beeper is not so narrowly confined. The beeper has the capacity to obtain information about location and movement despite their effective concealment from the public at large. Indeed, it is precisely to exploit this capacity that the beeper is used.

To decide whether the use of a beeper impairs privacy rights protected by the Fourth Amendment, courts must inquire whether the subject has sought to protect location and movement from view, and whether information conveyed by the beeper exceeds that accessible by visual observation. ${ }^{138}$ Because this determination depends

formation," regardless of whether the gathering is planned or accidental. Note, supra note 47 , at 974 .

The French opinion raises the related issue of when a beeper can be said to be tracking the location or movement of persons. No reported case has involved direct attachmont of a beeper to a person or his immediate effects. The prospect that beepers might be attached directly to persons has, however, been one reason that courts have given for imposing warrant requirements on beeper searches. See United States v. Holmes, 521 F.2d 859, 866 (5th Cir. 1975), aff'd en banc by an equally divided court, 537 F.2d 227 (5th Cir. 1976); United States v. Bobisink, 415 F. Supp. 1334, 1339 (D. Mass. 1976).

Beepers have, however, been attached to property subject to the control of particular individuals in order to monitor the location and movement of those individuals. The congruence between the movement of property and that of persons in these cases, together with the evident purpose of the police investigation, belies any attempt to distinguish monitoring the object from monitoring the individual. Probably the clearest example of tracking persons occurred in United States v. Holmes, 521 F.2d 859 (5th Cir. 1975), aff'd en banc by an equally divided court, 537 F.2d 227 (5th Cir. 1976), where the police knew in advance the defendant's probable involvement in a criminal conspiracy and wanted to follow him in order to locate other participants in the crime. Tracking of particular individuals, whose identity was known to the police in advance, also occurred in United States v. Hufford, 539 F.2d 32 (9th Cir.), cert. denied, 97 S. Ct. 533 (1976); and United States v. Bobisink, 415 F. Supp. 1334 (D. Mass. 1976), although in those cases the police were interested in the movements of property as well. The only case in which the police interest in property arguably outweighed that in individuals was United States v. Emery, 541 F.2d 887 (Ist Cir. 1976). There the beeper was attached to a parcel sent through the mails, and police did not know the identity of the recipient until shortly before arrest.

138. The privacy of location and movement, like the privacy of conversation, may be vulnerable to search pursuant to third party consent. No court has expressly focused on this issue. Although cases such as United States v. Abel, 548 F.2d 591 (5th Cir. 1977), cert. denied, 45 U.S.L.W. 3788 (U.S. June 6, 1977), have assumed that a party who can effectively consent to attachment of the beeper can also consent to monitoring, this result does not necessarily follow. The Fourth Amendment's protection of the privacy of location and movement may overlap its protection of property against physical intrusion, but the scope of the two may not be coextensive.

To determine whether consent for monitoring is valid, courts must consider whether the individual giving consent has authority to permit surveillance of those matters the beeper tracks. Where the object of the tracking is only property, the consenting individual's degree of control over the property is likely to be the determinative factor. See note 116 supra. Ownership alone may be insufficient to validate consent if the owner has 
heavily upon factual circumstances, it is impossible to say in the abstract precisely when electronic tracking may invade privacy of location and movement. In certain cases, however, the probability of such an invasion is extremely high.

The most obvious invasion occurs where a beeper monitors the location or movement of persons or property within an enclosed, private area where reasonably curious members of the public may not go. In these circumstances the beeper conveys information concerning matters that have been sealed entirely from public view. ${ }^{139}$ Such matters may of course be negligently exposed to others. ${ }^{140}$ If, for example, the lights are on and the curtains are not drawn, a reasonably curious passerby might take note of movements inside a house. ${ }^{141}$ But a beeper does not rely on such fortuitous circumstances; it performs its task even when all apertures have been tightly shut.

Although an individual's travels or those of his property may take place in public, they may be protected from observation with almost absolute certainty. A person who enters a closed vehicle in an enclosed garage and then is chauffered to an equally private destination has effectively precluded observation of his passage by others. Similarly, a package loaded onto an enclosed truck in a private warehouse and then transported to another warehouse can escape public

surrendered the property into another's care. But if an individual maintains a continuing interest in possession or use, such that he might direct the property's return or other disposition at any time, then his consent for surveillance should relieve necessity for a warrant. Even without such authority, an informant with knowledge amounting to certainty concerning the property's location and route might, as an alternative to notifying the police directly, permit them to engage in electronic tracking. Cf. United States v. White, 401 U.S. 745 (197I) (plurality opinion of White, J.) (discussed at note 107 supra).

A more difficult case arises where the beeper is used to track the location or movement of persons. An individual's movements are unlikely, except perhaps in the course of employment, to be subject to another person's authority or control. Use of beepers to track persons thus should require a warrant in most circumstances. Again, however, White would permit warrantless monitoring through the consent of an informant, e.g., a travelling companion having knowledge of his associate's location or movement.

139. See United States v, Kim, 415 F. Supp. 1252 (D. Hawaii 1976) (warrantless telescopic surveillance of interior of home violates Fourth Amendment). Current beeper technology probably lacks sufficient precision to permit monitoring of an individual's movements within close quarters. As technology improves, however, this kind of monitoring may become possible. Even now, a beeper may be used to determine whether a package secluded on private property has been opened. See United States v. Emery, 542 F.2d 887, 888 \& n.1 (1st Cir. 1976); note 3 supra.

140. See, e.g., United States v. Alewelt, 532 F.2d 1165, 1168 (7th Cir.), cert. denied, 429 U.S. 840 (1976) (defendant who placed jacket on coat rack in public lobby charged with knowledge that others might peer into pockets). See Note, $A$ Man's Home Is His Fort, supra note 65 , at 70-72, 75-77.

141. See, e.g., People v. Berutko, 71 Cal. 2d 84, 91-94, 453 P.2d 721, 725-26, 77 Cal. Rptr. 217, 221-22 (1969) (not a search where government agents looked through opening in curtains). 
notice. In either case, a beeper capable of tracking the movements of the individual or the package intrudes on protected privacy. ${ }^{142}$

Furthermore, there may be circumstances where an individual who has taken no steps to avoid observation by the public, and has thus "assumed the risk" of visual observation, ${ }^{143}$ may still claim Fourth Amendment protection against electronic monitoring. A traveler in public may be seen by many people, and his location at any given point may be known. It is also possible that reasonably curious persons might follow him for relatively brief periods and short distances. But continuous tailing by one person for a long distance or time is unlikely. ${ }^{144}$ An individual may thus be entitled to rely on the privacy of his "route," even if segments of it are exposed. When a beeper is used to track an individual's route by continuous and lengthy monitoring, the individual's privacy may thus be invaded though he took no apparent steps to protect it. ${ }^{145}$

142. An individual has several other protective means at his disposal: he may go out only for brief periods; he may travel at hours when the streets are likely to be empty; he may travel by circuitous routes; he may disguise his identity; or he may resort to places where others are unlikely to follow. Similar additional means are available for concealing the location and movement of property.

That an individual does not sacrifice entirely his rights to privacy by entering a public place is well established, despite occasional dicta to the contrary. See Cardwell v. Lewis, 417 U.S. 583, 591 (1974) (plurality opinion of Blackmun, J.) ("the exercise of a desire to be mobile does not, of course, waive one's right to be free of unreasonable government intrusion"); Terry v. Ohio, 392 U.S. 1, 9 (1968) ("unquestionably [one is] entitled to the protection of the Fourth Amendment as he walk[s] down the street"). But see Bowles v. United States, 439 F.2d 536, 540 (D.C. Cir. 1970), cert. denied, 401 U.S. 995 (1971) (en banc) (Fourth Amendment "is not a shield against the inevitable loss of privacy which accompanies one's decision to go out into the world and mingle with his fellow man").

143. See United States v. Hufford, 539 F.2d 32, 34 (9th Cir.), cert. denied, 97 S. Ct. 533 (1976) (person traveling in public subject to observation by government agents as well as general public); cf. United States v. White, 401 U.S. 745, 752 (1971) (plurality opinion of White, J.) (person making oral disclosures takes risk that intended auditor of conversation may disclose contents to police).

144. The extent to which a reasonably curious person might follow another individual is a matter that does not admit of precise determination. Certainly, however, it is possible that one person might follow another for several city blocks, or even across a fairly large town, without passing the bounds of reasonable curiosity. By contrast, a 24-hour "tail" of another's movements, or pursuit of an individual over a distance of 50 or 100 miles, would signify more than normal curiosity in that person's affairs.

145. The argument presented here suggests that even long-term visual surveillance may result in a search subject to Fourth Amendment warrant requirements. The invasion of privacy inherent in long-term spying has periodically been recognized, although objection to this mode of police investigation usually focuses on the deceptiveness rather than the duration of the investigatory techniques. Note, Judicial Control of Secret Agents, 76 YALE L.J. 994, 1018-19 (1967). See Osborn v. United States, 385 U.S. 323, 344-48 (1966) (Douglas, J., dissenting) (arguing that "planting" of government spies implicates Fourth Amendment); Amsterdam, supra note 75, at 407.

Lengthy observation without deception may also seriously curtail an individual's privacy. See Giancana v. Johnson, 335 F.2d 366 (7th Cir. 1964), cert. denied, 379 U.S. 1001 (1965) (district court granted preliminary injunction against 24-hour FBI surveillance of 
The reported beeper cases illustrate the kinds of privacy invasion that result from monitoring. Several cases have involved the tracking of property or persons whose movements remained secluded from public view, both during their transportation over public thoroughfares and at their final destination. ${ }^{140}$ In each case a substantial interest in privacy was invaded by the tracking activity. ${ }^{14 \pi}$ A somewhat more difficult situation is presented by those cases in which beepers were used to track motor vehicles and their occupants on public highways. In many of these cases, however, the vehicles were driven by circuitous routes, on long journeys, or to remote destinations. ${ }^{1 * 8}$ The most striking example is United States v. French, where the journey traversed four states. ${ }^{149}$ In these cases, the operators of the monitored vehicles

plaintiff's movements on grounds that constitutional rights of privacy violated; circuit court dismissed for failure to allege damages meeting jurisdictional amount requirement); cf. Weinreb, supra note 93, at $82-83$ (continuous television surveillance of open areas where individuals accustomed to go unobserved may invade privacy). But see United States v. Gonzalez-Rodriguez, 513 F.2d 928 (9th Cir. 1975) (one month of continuous surveillance without probable cause permitted; subsequent warrantless search pursuant to arrest at border justified on grounds of exigency).

146. Secluded property was tracked in United States $v$. Hufford, 539 F.2d 32, 34 (9th Cir.), cert. denied, 97 S. Ct. 533 (1976) (chemical drum enclosed in truck); United States v. Perez, 526 F.2d 859, 862 (5th Cir.), cert. denied, 429 U.S. 846 (1976) (television placed in automobile); United States v. Bobisink, 415 F. Supp. 1334, 1336 (D. Mass. 1976) (package of chemicals in van); and United States v. French, 414 F. Supp. 800, 802 (W.D. Okla. 1976) (bags of marijuana enclosed in truck and barn).

Tracking of secluded persons (at their destinations) occurred in, e.g., United States v. Holmes, 521 F.2d 859 (5th Cir. 1975), aff'd en banc by an equally divided court, 537 F.2d 227 (5th Cir. 1976) (occupants of van traced to secluded farm); United States v. Bobisink, 415 F. Supp. 1334 (D. Mass. 1976) (purchasers of chemicals traced to private house); and United States v. French, 414 F. Supp. 800 (W.D. Okla. 1976) (driver of vehicle traced to private farm).

147. This is so even if the tracking involved property that was contraband. It has been suggested that one can have no reasonable expectation of privacy in contraband. See United States v. Emery, 541 F.2d 887, 889-90 (1st Cir. 1976) (contraband is property which defendant "had no right to possess" and in which he "had no reasonable expectation of privacy"); United States v. French, 414 F. Supp. 800, 804 (W.D. Okia. 1976) (one can have "no legitimate purpose" in concealing contraband); note 131 supra. This suggestion conflicts with the analysis developed in this Note. It rests on the social acceptability of the privacy interest at stake rather than on the means taken to protect it. It seems clear that contraband, like Katz's illegal conversations, may be as securely protected from detection by reasonably curious persons as any other item. Where contraband's location and movement are so protected, use of a beeper should require a judicial warrant. Moreover, where contraband is used as a means for tracking the movements of persons or other items of property, the tracking may invade independent privacy interests, requiring a warrant whether or not the contraband itself is protected by the Fourth Amendment. See note 131 supra.

1.48. E.g., United States v. Hufford, 539 F.2d 32, 33 (9th Cir.), cert. denied, 97 S. Ct. 533 (1976) (defendants took circuitous route); United States v. Holmes, 521 F.2d 859, 861.62 (5th Cir. 1975), aff'd en banc by an equally divided court, 537 F.2d 227 (5th Cir. 1976) (departure in early morning hours, travel to remote and sparsely populated region).

149. 414 F. Supp. 800, 802 (WV.D. Okla. 1976) (movement also involved surreptitious exchange of vehicles). The court noted that visual as well as electronic surveillance was maintained at all times. Id. But see note 145 supra. 
took steps reasonably calculated to preserve their movements from detection by the public at large; arguably they were protected by the Fourth Amendment from continuous police monitoring. ${ }^{150}$

In several cases beepers continued to monitor their subjects after they entered private enclosures. ${ }^{151}$ Because the beepers were attached to items not likely to be secured on an individual's person, the only information conveyed concerning location was that the monitored item had entered onto private property. It is, of course, possible to observe entry from a public vantage, and so it might be argued that the beeper conveyed only information that was accessible to the reasonably curious person, though its signals originated from a private enclosure. ${ }^{152}$ To determine whether entry was in fact exposed to the public, however, it is necessary to consider whether the individual took steps to guard his entry against observation. Where such precautions were taken, even if they consisted of nothing more than ascertaining that no one was in sight, use of a beeper intruded on privacy.153 In at least one case, the fact of entry appears to have been concealed..54 In the other cases, the facts are inconclusive.

\section{Applicability of Exceptions to the Warrant Requirement}

Electronic tracking, then, generally involves both physical and nonphysical invasions of Fourth Amendment rights. It remains to be seen, however, whether these invasions may be justified as an exception to Fourth Amendment restraints. ${ }^{155}$ Generally exceptions are justi-

150. Tracking of airplanes presents a different issue. The location of airborne vehicles is regularly monitored by government radar, a form of "regulatory" search that may be excepted from Fourth Amendment warrant requirements. See p. 1497 infra. But this rationale does not justify the holding in United States v. Pretzinger, 542 F.2d 517,520 (9th Cir. 1976) (per curiam), that electronic tracking of airplanes is not a search. First, tracking the "route" of an individual airplane may intrude beyond the government's regulatory authority. See People v. Smith, 136 Cal. Rptr. 764, 767, 771 (Ct. App. 1977). Second, since it is highly unlikely that the reasonably curious person would follow an airplane, the airplane user need not make a special effort to preserve his privacy. See p. 1494 supra.

151. See note 20 supra (citing cases).

152. An argument similar to this was made by the court in United States v. French, 414 F. Supp. 800, 805 (W.D. Okla. 1976).

153. One commentator has argued that for similar reasons use of police airplanes and helicopters to conduct airborne visual searches may intrude on privacy. Comment, supra note 103 , at $527-36$.

154. United States v. Holmes, 521 F.2d 859, 861-62 (5th Cir. 1975), aff'd en banc by an equally divided court, 537 F.2d 227 (5th Cir. 1976) (defendant traveled at night and during early morning hours, thereby escaping visual surveillance from both the ground and the air).

155. Several judicial opinions have suggested that warrantless beeper searches are justifiable under standard exceptions to the warrant requirement. See note 167 infra. 
fied under either of two primary rationales. First, a search based on probable cause may be conducted without a warrant when "exigent circumstances," such as danger,"150 "hot pursuit,"15t or "fleeting opportunity"158 for search, make compliance with the warrant requirement impracticable. ${ }^{159}$ Second, a warrantless search that is routine, limited, and regulatory in nature may be justified, even in the absence of probable cause, on the ground that the narrow scope of such a search satisfies the "reasonableness" requirement of the Fourth Amendment. ${ }^{160}$ Only in rare instances should either of these exceptional rationales be used to justify beeper searches. ${ }^{161}$

156. McDonald v. United States, 335 U.S. 451,455 (1948) (warrant requirement may not be ignored except in "grave emergency").

157. Warden v. Hayden, 387 U.S. 294, 298-300 (1967) (warrantless search of building for robbery suspect within minutes of robbery not a violation of Fourth Amendment). The term "hot pursuit" appears in the concurring and dissenting opinions. Id. at 310 (Fortas, J., concurring); id. at 321 (Douglas, J., dissenting).

158. Coolidge v. New Hampshire, 403 U.S. 443, 459.60 (1971) (plurality opinion of Stewart, J.) (automobile search permitted only when justified by "fleeting opportunity"); Chambers v. Maroney, 399 U.S. 42, 48.51 (1970) (same).

159. Searches under exigent circumstances also include searches of motor vehicles, Chambers v. Maroney, 399 U.S. 42 (1970); Carroll v. United States, 267 U.S. 132 (1925); searches incident to arrest, Chimel v. California, 395 U.S. 752 (1969) (limits of rationale defined; search in instant case illegal); Agnello v. United States, 269 U.S. 20 (1925); and "stop and frisk" searches, Terry v. Ohio, 392 U.S. 1 (1968). See Amsterdam, supra note 75, at 374; The Supreme Court, 1966 Term, 81 HARv. L. Rev. 110, 117-21 (1967). For a thorough catalogue of the circumstances that have been held to establish exigency, see Guzman v. Estelle, 493 F.2d 532, 536-37 (5th Cir. 1974).

160. The concept of "reasonable search" has its roots in pre-Katz doctrine. It rests on the notion that under certain circumstances a search may be reasonable within the meaning of the Fourth Amendment although the police do not establish probable cause and obtain a warrant. See See v. City of Seattle, 387 U.S. 541 (1967) (warrant, but not probable cause, required for administrative search); Camara v. Municipal Court, 387 U.S. 523 (1967) (same); Rabinowitz v. United States, 339 U.S. 56 (1950), overruled on other grounds, Chimel v. California, 395 U.S. 752 (1969) (warrantless search may be reasonable even though opportunity to obtain warrant existed). See generally Greenberg, supra note 71; LaFave, Administrative Searches and the Fourth Amendment: The Camara and See Cases, 1967 Sup. Cr. Rev. 1; The Supreme Court, 1966 Term, 81 HaRv. L. Rev. 69, 120-21 (1967).

Warrantless searches that have been upheld on the grounds of reasonableness in the absence of probable cause include: airport searches, United States v. Edwards, 498 F.2d 496 (2d Cir. 1974); border searches, United States v. Martinez-Fuerte, 428 U.S. 543 (1976); automobile inventory searches, South Dakota v. Opperman, 428 U.S. 364 (1976); and vehicle identification checks, United States v. Montgomery, No. 75-1715, majority slip op. at 14-17 (D.C. Cir. May 26, 1977); United States v. Polk, 433 F.2d 644 (5th Cir. 1970). For one commentator's effort to establish a common theoretical foundation for exceptions based on exigent circumstances and those based on the doctrine of reasonableness, see Weinreb, supra note 93 , at $79 \cdot 80$.

161. It might also be asserted that beeper searches may be justified under two other exceptions to the warrant requirement that permit searches of items in "open fields" and of items in "plain view." See Hester v. United States, 265 U.S. 57 (1924) (open fields exception); Harris v. United States, 390 U.S. 234, 236 (1968) (plain view exception). To assert that tracking is a search in open fields is to claim that it is analogous to visual 
The rationale supporting warrantless searches of a routine, limited, and regulatory nature is clearly inapplicable ${ }^{\mathbf{1 6 2}}$ and no beeper court has ever suggested the contrary. Beeper searches are not brief, minimally intrusive, or routine. ${ }^{163}$ Moreover, electronic tracking lacks the procedural safeguards that have generally been required under this exception. ${ }^{164}$ Even if such procedures were developed, the variety of

observation. This argument has already been shown to be without foundation. See pp. 1491-92 supra.

The plain view exception, however, may apply to electronic tracking in certain circumstances. Originally, the plain view exception was used to justify search and seizure of items discovered during the course of a legal search but not included in the initial warrant. See Marron v. United States, 275 U.S. 192, 198-99 (1927). The doctrine has since been expanded to permit search and seizure of "objects falling in the plain view of an officer who has a right to be in the position to have that riew." Harris v. United States, 390 U.S. 234, 236 (1968).

Applied literally, the exception would not permit the use of beepers, because the exception pertains in terms only to visual observation by an officer. A variant of the plain view theory, however, has developed in the context of wiretapping. This variant permits use of evidence discovered during the course of legal surveillance, even if it is not covered in the scope of the original warrant. See United States v. Cox, 449 F.2d 679, 686-87 \& n.10 (10th Cir. 1971), cert. denied, 406 U.S. 934 (1972). The wiretap is analogized to a police presence, so that items within its reach are considered to be within the "vicw" of law enforcement officials.

If this theory were applied to beepers, it would require that the beeper be legally in the place from which the "view" is obtained. Thus, while plain view may justify subsequent tracking, it may not justify the original placement of the beeper. If the beeper is illegally attached, then the analogy fails. Moreover, even where attachment is legal, the plain view exception covers only those subsequent discoveries that are inadvertent. See Coolidge v. New Hampshire, 403 U.S. 443, 469 (1971) (plurality opinion of Stewart, J.). Courts have long recognized that unless discoveries justified under plain view are accidental, police could manipulate the exception to avoid the particularity requirements for search and seizure set by the Fourth Amendment, see p. 1506 infra.

Despite the various limitations on the plain view exception, it is possible to imaginc circumstances in which the exception might justify warrantless clectronic tracking. If police were to obtain a warrant for electronically tracking one person's movements by car, and the automobile was subsequently used by someone else, inadvertently discovered information about the second person's movements could be used by the police although the second individual was not covered by the original wariant.

162. The theory itself may be of dubious validity, to the degree that it defines Fourth Amendment protections in terms of the relationship between the individual and the government. Taken to its extreme, the theory would permit the government to emasculate the warrant requirement in many situations merely by commencing a program of wholesale search pursuant to some regulatory power, and thereby creating the "lesser expectation of privacy" from which the search derives its justification. See p. 1475 supra. Probably the most striking example of this phenomenon has come as a result of the increase in airport security in recent years. See, e.g., United States v. Edwards, 498 F.2d 496, 498-99 (2d Cir. 1974) (government may take reasonable measures to protect against air piracy; travellers on notice that they may be searched).

163. The characteristics of electronic tracking contrast with those of regulatory searches justified as reasonable. Cf. United States v. Brignoni-Ponce, 422 U.S. 873, 880 (1975) (roving border patrol checks usually last “no more than a minute"); United States v. Montgomery, No. 75-1715, majority slip op. at 13 (D.C. Cir. May 26, 1977) (duration of search one of several criteria determining intrusiveness); United States v. Polk, 433 F.2d 644, 646-47 (5th Cir. 1970) (vehicle identification check involved detention of extreme brevity).

164. The developing case law suggests that to qualify for this exception, a search must be regulated by procedures that are standardized and systematically enforced, that 
circumstances in which beepers may be used would require the exercise of considerable discretion by police officers, thus leaving room for arbitrary action. ${ }^{165}$ Indeed, the beeper's secrecy enhances the potential for abuse. Finally, the government does not have the broad regulatory power over individuals' movements that could justify excepting electronic tracking from the warrant requirement under the routine search rationale. ${ }^{106}$

The exigency rationale is equally inapplicable in most circumstances. ${ }^{107}$ Exigency arising from imminent danger to police or others is unlikely to justify electronic tracking because tracking does nothing to mitigate such danger. Attaching a beeper does not aid police in gaining immediate control over dangerous weapons or persons. A beeper might be used to lead police to the persons or items thought to be dangerous, but the passage of time required for that result would eliminate the search's exigency ${ }^{16 s}$ and destroy the justification for not seeking a warrant.

It might be possible for police to use the beeper, however, as an effective aid in "hot pursuit" of a criminal. For example, during a

minimize potential abuse from selective harassment, and that place no stigma of suspected wrongdoing on the subjects of the search. Compare South Dakota v. Opperman, 428 U.S. 364, 369 (1976) (inventory scarch controlled by standardized procedures) and United States v. Edwards, 498 F.2d 496, 500 (2d Cir. 1974) (no stigma attached to airport search procedures that apply to all passengers alike) with United States v. Ortiz, 422 U.S. 891, 895-96 (1975) (checkpoint procedures allow too much discretion and involve too much potential for selective harassment to mcet Fourth Amendment standards for reasonableness) and United States v. Montgomery, No. 75-1715, majority slip op. at 6-7, 15 (D.C. Cir. May 26, 1977) (roving traffic stop based on officer's "inarticulate hunch" derived from conduct consistent with innocent behavior conferred undue discretion; regulatory search must be systematic).

165. For an example of an effort to overcome this problem, see Drug Enforcement Administration Domestic Operations Guidelines, Dec. 28, 1976, reprinted in 20 Crum. L. REP. (BNA) 3055, 3058 (Feb. 2, 1977) (DEA guidelines for use of beepers requiring either authorization by a "Group Supervisor or higher authority" or "a Federal court order in the nature of a warrant ... if installation involves a trespass or if otherwise required by the Federal case law"). These DEA procedures, however, provide no systematic criteria for determining when tracking is to be authorized.

166. Cf., e.g., United States v. Ramscy, 45 U.S.L.T. 4577, 4579-82 (U.S. June 6, 1977) (sovereign control over entry across borders together with congressional authorization justifies warrantless search on "reasonable suspicion" of incoming international mail); South Dakota v. Opperman, 428 U.S. 364, 368 (1976) (automobile inventory search justified in part by police traffic regulatory functions); United States v. Edwards, 498 F.2d 496, 498, 500 (2d Cir. 1974) (airport search justified by government's strong regulatory interest in protecting air travelers' safety).

167. Only one beeper decision has rested expressly on a finding of exigent circumstances. United States v. Frazier, 538 F.2d 1322, 1324-25 (8th Cir. 1976), cert. denied, 97 S. Ct. 823 (1977) (automobile and hot pursuit exceptions). The existence of exigent circumstances was adopted as an alternative rationale in United States v. French, $414 \mathrm{~F}$. Supp. 800, 804-06 (W.D. Okla. 1976) (also invoking open fields exception), and was urged by the dissent in United States v. Holmes, 537 F.2d 227, 229 (5th Cir. 1976) (en banc; per curiam) (Ainsworth, J., dissenting).

168. See The Supreme Court, 1966 Term, 81 HARv. L. REv. 110, 122 (1967). 
bank robbery, a bank teller acting as an agent for the police might slip a beeper into a money bag, thereby enabling the police to track the culprits. ${ }^{169}$ To serve this purpose, the beeper would have to be attached at the scene of the crime or immediately thereafter, at a time when it would be impossible for police to obtain a warrant. The hot pursuit doctrine, however, would justify only brief tracking: longlasting monitoring would call into question the degree to which the pursuit was in fact "hot." 170

Exigency based on a "fleeting opportunity" permits warrantless searches in situations where the delay necessary to procure a warrant would destroy the opportunity for a fruitful search, as, for example, where the objects of the search are likely to be destroyed, concealed, or removed. ${ }^{171}$ Since the subjects of electronic tracking are mobile and are likely to avoid police surveillance unless monitored, it might appear that a fleeting opportunity exists in nearly every beeper search. To apply the fleeting opportunity exception to beeper searches, however, substantially alters its scope. In its typical application, the doctrine permits a police officer to conduct a search for physical evidence immediately in his presence. ${ }^{172}$ This form of warrantless search is often justified as a less intrusive alternative to detention while a warrant is being procured. ${ }^{173} \mathrm{~A}$ beeper does nothing to aid such

169. This was done in United States v. Bishop, 530 F.2d 1156 (5th Cir.), cert. denied, 97 S. Ct. 133 (1976).

170. Use of the "hot pursuit" rationale in United States v. Frazier, 538 F.2d 1322, 1325 (8th Cir. 1976), cert. denied, 97 S. Ct. 823 (1977), may not have been justificd. Although the situation was grave because the extortioner under surveillance was carrying explosives, and although the pursuit was brief, the beeper was placed on the defendant's car the night before the extortion attempt was expected to occur. Since the police were operating on information from a reliable informant, and since there were apparentiy no exigent circumstances at the time the beeper was placed, it is at least arguable that there was adequate opportunity to obtain a warrant.

171. The classic example is the search of an automobile on the open highway, where the vehicle and its contents may be easily removed unless an immediate search is conducted. See Carroll v. United States, 267 U.S. 132 (1925). The impracticability of obtaining a warrant may no longer be an essential element of a justification for warrantless automobile searches. See Cardwell v. Lewis, 417 U.S. 583, 595-96 (1974) (plurality opinion of Blackmun, J.). But the requirement seems to be intact with respect to other exceptions. See United States v. Chadwick, 45 U.S.I.W. 4797, 4801 (U.S. June 21, 1977) (opportunity to obtain warrant defeats claim of exigency for warrantless search of locked trunk taken into police custody).

172. See Chimel v. California, 395 U.S. 752, 763 (1969) (exigency rationale for search incident to arrest permits only search of areas subject to arrestee's immediate control in order to prevent physical danger or destruction of evidence); United States $v$. Chadwick, 45 U.S.L.W. 4797,4801 (U.S. June 21, 1977) (locked trunk seized contemporancously with arrest may not be subsequently searched without a warrant; affirming Chimel); Note, supra note 145, at 1018, 1019 .

173. Cf. Chambers v. Maroney, 399 U.S. 42, 52 (1970) (automobile search justificd in part on ground that it is less intrusive than posting of police guard until warrant can be obtained). 
a search. Rather, the beeper's purpose is to convey intangible evidence not immediately present, indeed not yet in existence. The current location of the item or person is already known; the beeper's only purpose is to track future location and movement, matters beyond the scope of a search justified by exigency. ${ }^{174}$

There are two counterarguments that support application of the "fleeting opportunity" doctrine to beepers. First, the beeper could operate as an alternative to detention. If, for example, cause arises to search an automobile, electronic tracking might be used to monitor the vehicle's location until a warrant can be procured. Such a use of the beeper, however, would only be permissible as an alternative to immediate search, since the exigent circumstance justifying the attachment would evaporate once the search took place. Moreover, using the beeper would be more intrusive than search on the spot, because in addition to enabling a subsequent search of the automobile's contents no less intrusive than a spot search, the beeper would allow a continuing surveillance of the vehicle's location during the intervening period. For this reason immediate search should be required as the less intrusive alternative.

Second, opportunities to attach the beeper may themselves be fleeting. The delay involved in procuring a warrant may allow an opportunity for attachment of the beeper to pass, thereby frustrating the search. ${ }^{175}$ Police may be unable to predict when an opportunity will arise to place a beeper, and the cumbersome procedure of obtaining a warrant may prevent them from exercising those opportunities

174. United States v. French, 414 F. Supp. 800, 804 (W.D. Okla. 1976), argues that a kind of continuing exigency exists when a beeper is used to track property that might otherwise be removed or destroyed. In that case, however, "exigency" was created by the government agents themselves, when they permitted contraband marijuana to be delivered rather than seizing it at the border as they unquestionably had a right to do. When the search and the exigent circumstance are thus separated in time, a warrant is usually required. See Vale v. Louisiana, 399 U.S. 30 (1970) (arrest of suspect in front of his house does not permit search of interior after arrest accomplished); cf. G.M. Leasing Co. v. United States, 97 S. Ct. 619, 624-25, 631-32 (1977) (tax authorities who had lien on petitioner's property could not justify on exigency grounds a warrantless search of petitioner's office since authorities had delayed entry while maintaining surveillance for several days). But see United States v. Mitchell, 538 F.2d 1230, 1233 (5th Cir. 1976), cert. denied, $97 \mathrm{~S}$. Ct. 1578 (1977) (en banc) (exigency arising from mobility of contraband delivery truck not eliminated by constant surveillance by agents prior to arrest).

175. This argument could have been raised both in United States v. Holmes, 521 F.2d 859 (5th Cir. 1975), aff'd en banc by an equally divided court, 537 F.2d 227 (5th Cir. 1976), and in United States v. Bobisink, 415 F. Supp. 1334 (D. Mass. 1976). In the former case a beeper was attached to the defendant's automobile while he was conferring with an undercover agent to finalize plans for an illegal drug transaction. 521 F.2d at 861. But see p. 1502 \& note 178 infra. In the latter case, although one beeper had already been attached to a package of chemicals ordered by the defendants, a second beeper was placed on their rented van while they were in the process of picking up their purchase, 415 F. Supp. at 1336. 
that become available. But this problem is significantly different from the kinds of fleeting opportunity that traditionally justify warrantless intrusion. What converts a fleeting opportunity into an exigent circumstance is the simultaneous conjunction of cause and opportunity for search. ${ }^{176}$ In the beeper situation, cause ordinarily arises prior to attachment. Therefore, insistence on a warrant would seldom frustrate a search: once the warrant is obtained, police could await an appropriate opportunity for attachment. ${ }^{1 i t}$

Indeed, in most of the reported beeper cases, police had ample opportunity to obtain a warrant before attaching a beeper. In Holmes, for example, police could anticipate well in advance the planned meeting between their agent and the suspects they wished to track. ${ }^{178}$ In United States v. Emery and in French, delivery of contraband discovered upon entry into the United States could have been delayed in order to allow time to secure a warrant. ${ }^{179}$

In the rare case in which cause and opportunity do arise simultaneously, the police should be permitted to claim an exigent circumstance. They should be required, however, to apply for a warrant as soon as possible after the tracking begins. ${ }^{180}$

\section{Compliance With Warrant Requirements: Formulating Special Procedures}

In all but a few exceptional circumstances, warrants should be obtained before electronic tracking is begun. Consequently, it is necessary to consider how the Fourth Amendment's probable cause and particularity requirements for search warrants should be applied to

176. See, e.g., Dorman v. United States, 435 F.2d 385, 390 (D.C. Gir. 1970) (if warrant requirement is waived because of exigency, search must be prompt).

177. FED. R. CRIM. P. $4 \mathrm{I}$ (c)(2) was recently amended to permit preliminary warrant authorizations to be obtained by telephone. 18 U.S.C.A. app. at 18 (West Supp. 1977) (amendment submitted to Congress by Supreme Court); Act of July 8, 1976, Pub. L. No. 94-349, 90 Stat. 822 (postponing effective date of amendment to August 1977). This change will significantly reduce the burden of antecedent justification for search in exigent situations and may render the exigency rationale inapplicable for nearly all beeper searches. Cf. United States v. Turner, 21 Crim. L. Rep. (BNA) 2289 (2d Cir. Junc 2, 1977) (upholding telephone authorization as sufficient compliance with Fourth Amendment warrant requirement even absent statutory provision).

178. 537 F.2d 227, $228-29$ (5th Cir. 1976) (en banc; per curiam) (Ainsworth, J., dissenting). An additional reason for not applying the fleeting opportunity doctrine in Holmes is that the prerequisite of probable cause, see p. 1497 supra, had not been satisfied. 521 F.2d at $866-67$.

179. United States v. Emery, 541 F.2d 887, 888 (1st Cir. 1976); United States v. French, 414 F. Supp. 800,801 (W.D. Okla. 1976).

180. The requirement of prompt post hoc application for a warrant applies when exigent circumstances are used to justify a warrantless wiretap. See 18 U.S.C. $\$ 2518(7)$ (1970) (application for warrant must be made within 48 hours after placement of tap in cases of exigency). 
beepers. Electronic tracking is an unusual form of search because it is not limited to a particular time or place. Like other forms of electronic surveillance, the beeper is indiscriminate; it may convey information totally irrelevant to the purposes of the search. Therefore, it is constitutionally necessary to establish special beeper warrant procedures similar to those mandated for electronic eavesdropping in Berger $v$. New York ${ }^{181}$ and subsequently embodied in the federal wiretapping statute. ${ }^{152}$ The need for special warrant procedures for beepers can be demonstrated by applying the concepts of probable cause and particularity to electronic tracking.

\section{A. Probable Cause}

Probable cause for search and seizure has two requisites. First, the items or information sought by the police must be "seizable": ${ }^{183}$ the government must assert a valid interest in obtaining them by virtue of their relationship to the prosecution or detection of a crime. ${ }^{184}$ Second, that interest must be served by the proposed search: the items or information to be seized must be likely to be discovered in the place to be searched. ${ }^{185}$ By analogy to conventional methods of search and seizure, the item "seized" by electronic tracking is information concerning the movements of the property or persons tracked. The place "searched" is the item to which the beeper is attached. The government, then, must establish a valid interest in knowing the movements

181. 388 U.S. 41,60 (1967).

182. 18 U.S.C. $\$ \S 2510-2518$ (1970).

183. Note, Search and Seizure in the Supreme Court: Shadows on the Fourth Amendment, 28 U. ChI. L. REv. 664, 687 (1961).

184. Warden v. Hayden, 387 U.S. 294, 300-10 (1967), paints with a broad brush the range of "seizable" items. Nonetheless, it is clear that some nexus between the information or object seized and the criminal activity being investigated is required. Otherwise, the government could spy on activities in which it had no legitimate interest and which might in fact be protected by constitutional guarantee. See United States v. United States District Court, 407 U.S. 297, 314-21 (1972) (warrantless "domestic security" wiretapping allows harassment of those with unorthodox political views in violation of First as well as Fourth Amendment). Tracking of location and movement, without an adequate showing of its connection to criminal activity, might similarly infringe on constitutionally protected freedoms of travel and assembly.

185. Carroll v. United States, 267 U.S. 132, 149 (1925) (probable cause for automobile search requires "a belief, reasonably arising out of circumstances known to the seizing officer, that an automobile or other vehicle contains that which by law is subject to seizure"); Note, supra note 183, at 687; see Brincgar v. United States, 338 U.S. 160, 166 (1949) ("ultimate facts" establishing probable cause for scarch of suspected liquor runner's automobile included knowledge that route and mode of transportation had been used in prior illicit dealings); cf. United States v. Holmes, 521 F.2d 859, 863 n.7, 866 (5th Cir. 1975), aff'd en banc by an equally divided court, $537 \mathrm{~F} .2 \mathrm{~d} 227$ (5th Cir. 1976) (district court held that placement of becper on van not supported by probable cause because agents had no reliable information on which to form belief that van would be used to transport marijuana). 
of the persons or property to be tracked, an interest arising out of their relation to criminal activity; and it must be able to show that the means of tracking to be employed, including the timing of attachment and the actual placement of the beeper are likely to produce the information sought.

The chief difficulty in establishing probable cause for tracking lies in the required demonstration of a significant relationship between information about the location and movement of individuals or property and the government's gathering of evidence concerning a crime. Although location and movement may at times be material evidence of crime, ${ }^{186}$ in most situations the relation to criminal activity is more remote. Ordinarily the government seeks to trace the movements of persons or property on the theory that they will lead to a locus of criminal activity. ${ }^{187}$ The chief value of tracking is to facilitate subsequent searches for criminals and evidence of crime once this locus is discovered.

Because the information received through tracking is likely to be at least one step removed from the crime under investigation, government requests for a warrant to track an individual electronically may as often as not be based on "the merest of suspicions."188 To ensure that the beeper search is in fact justified, magistrates should require a showing of sound reasons for believing that the proposed tracking operation will reveal pertinent facts of criminal activity. Evidence tending to show that the property to be monitored may be an instrumentality of crime, or that the person to be monitored is likely to be one of the perpetrators, would supply the requisite nexus. ${ }^{189}$ In the absence of such evidence, there is an unacceptably high risk that electronic tracking may needlessly invade the privacy of innocent persons.

Even when a close nexus exists between surveillance of location and detection of crime, the government must show some reason why

186. An example would be where crossing state lines is a material element of the offense.

187. See, e.g., United States v. Hufford, 539 F.2d 32, 33 (9th Cir.), cert. denied, 97 S. Ct. 533 (1976) (attempt to locate site of illegal drug manufacture); United States v. Holmes, 521 F.2d 859, 861 (5th Gir. 1975), aff'd en banc by an equally divided court, 537 F.2d 227 (5th Cir. 1976) (attempt to locate site of illegal contraband).

188. United States v. Holmes, 521 F.2d 859, 866 (5th Cir. 1975), aff'd en banc by an equally divided court, 537 F.2d 227 (5th Cir. 1976); cf. United States v. McCaleb, 45 U.S.L.W. 2520 (6th Cir. April 11, 1977) (activities consistent with innocent behavior do not establish cause for even limited scarch).

189. Similar requirements have been established for wiretapping and other forms of electronic surveillance. See 18 U.S.C. $\$ 2518(3)$ (a), (b), (d) (1970). 
electronic tracking is necessary. Electronic surveillance is one of the most intrusive methods of discovering the location of criminals or evidence of crime; less intrusive methods such as visual tailing, examination of lodging registrations and other public travel information, and questioning of witnesses might often be reasonable alternatives. To justify the greater intrusion of electronic tracking, the police should be required to show that these other methods of search are likely to be ineffective or unduly burdensome. ${ }^{190}$

Long-term electronic tracking runs the additional risk of "stale probable cause": 191 although an individual's movements may initially appear to be related to criminal activity, subsequent events may undermine the original justification. In order to halt the beeper's invasion of privacy once probable cause for a beeper warrant no longer exists, an issuing judge should include in the warrant express provisions for regular review of the progress of the search and should limit the absolute duration of the search to the shortest period consistent with demonstrated police needs. ${ }^{192}$

Once the "seizability" of location and movement is established, the means of search must be shown to be reasonably likely to produce the information sought. The government must indicate how it intends to attach the beeper, and the magistrate must judge whether the timing of the attachment and the placement of the beeper are likely to result in the seizure of appropriate information. ${ }^{193}$ Where the property to which the beeper is attached is closely related to the crime under investigation, this requirement presents no problem. Similarly, where the property is subject to exclusive possession by an individual suspect, attachment of a beeper is probably a reliable means of tracking his movements. But where property is likely to change hands or is subject to use by persons other than those under investigation, the danger of

190. Compare United States v. Bobisink, 415 F. Supp. 1334, 1337 (D. Mass. 1976) (where visual surveillance is a reasonable alternative there can be no urgent need for tracking) with Berger v. New York, 388 U.S. 41, 60 (1967) (there must be showing of exigency to justify not informing suspect of electronic eavesdropping).

191. See generally Comment, A Fresh Look at Stale Probable Cause: Examining the Timeliness Requirement of the Fourth Amendment, 59 IowA L. REv. 1308 (1974).

192. A similar problem with respect to electronic earesdropping led the Court to conclude in Osborn v. United States, 385 U.S. 323 (1966), that the potential for "indiscriminate use" of electronic surveillance places on courts a " "heavier responsibility" than usual to supervise the fairness of warrant procedures. Id. at $329 \mathrm{n} .7$ (quoting Lopez v. United States, 373 U.S. 427, 441 (1963) (Warren, C.J., concurring in the result)). See United States v. Ford, 414 F. Supp. 879, 884 (D.D.C. 1976), aff'd, 45 U.S.L.W. 2411 (D.C. Cir. Feb. 11, 1977) (judicial control over electronic surveillance must be strict).

193. See United States v. Ford, 414 F. Supp. 879, 884 (D.D.C. 1976), aff'd, 45 U.S.L.W. 2411 (D.C. Cir. Feb. 11, 1977); Comment, supra note 191, at 1308-09. 
unwarranted intrusions into the privacy of third parties may be too great to permit a warrant. ${ }^{104}$

\section{B. Particularity}

A search not only must be justified by a valid governmental interest but also must be narrowly confined to the particular places and things to which that interest extends. ${ }^{195}$ The requirement of particularity in warrant applications protects against general searches in which a single warrant is used as a "passkey" for intrusion into matters in which the government has no justifiable interest. ${ }^{106}$ Electronic tracking shares many of the problems of particularity that Berger associated with electronic eavesdropping. Tracking is a secretive, continuous, and indiscriminate form of search, which may convey much information concerning perfectly innocent movements. It may intrude on the privacy of third parties. It may comprise, in effect, a series of searches pursuant to a single showing of probable cause. Furthermore, because the subject of the search receives no notice of the surveillance, there is no opportunity for innocent parties to seek legal redress in cases of abuse. ${ }^{197}$

To remedy similar defects in electronic monitoring of conversations, Berger held that a valid warrant must be particularized by a description of the conversations to be intercepted, a limit on the duration of the search, a provision for discontinuing surveillance when the desired information is obtained, and a specification of the reason for withholding notice from the subjects of the search. ${ }^{198}$ These requirements, reinforced by the Court's holding in Katz, form the substance of the warrant requirements set forth in $\S 802$ of Title III of the Omnibus Crime Control and Safe Streets Act of 1968. ${ }^{199}$

\section{Proposed Warrant Procedures}

Title III provides a good index for warrant procedures that would adequately safeguard the use of beepers. To ensure that a beeper

194. The controlling standard is that there must be "no greater invasion of privacy ... than [is] necessary under the circumstances." Berger v. New York, 388 U.S. 41, 57 (1967). This standard does not, however, require a "rifle shot" search so limited that it picks up only information relevant to the crime. Even traditional searches are not so narrowly constrained. See United States v. Cox, 462 F.2d 1293, 1300-01 (8th Cir. 1972), cert. denied, 417 U.S. 918 (1974). The rule must be one of common sense. See note 200 infra.

195. Berger v. New York, 388 U.S. 41, 58 (1967).

196. See Harris v. United States, 331 U.S. 145, 157-62 (1947) (Frankfurter, J., dissenting).

197. 388 U.S. at 58-60.

198. Id.

199. 18 U.S.C. $§ 2518(1970)$. 
warrant is founded on probable cause, the following showings should be required:

- that a crime has been, is being, or is about to be committed;

- that tracking of the persons or property specified in the application is likely to reveal evidence of the crime, or the location of the criminals;

- that the persons or property to be tracked are directly involved in the crime;

- that alternative methods of investigation are likely to be burdensome or ineffective;

- that existing exigent circumstances justify withholding notice of the search. 200

To ensure that the search is conducted with the requisite particularity, the court order authorizing the search should include:

- a statement identifying the persons or property to be tracked;

- a statement narrowly defining the purpose of the search;

- a statement specifying the object on which and the method by which the beeper is to be attached;

- where possible, a limit on the geographical extent of the tracking operation;

- a limit on the time period during which the search may continue;

- a statement of conditions requiring termination of the search in advance of the specified time limit;

- provisions for submitting a return report on search activities;

- provisions for giving subsequent notice to the parties searched.201

200. These standards are drawn from $i d$. $\$ 2518(3)$. The first three, taken together, arc intended to "link up specific person, specific offense and specific place" and to ensure use "only under the most precise and discriminate circumstances." S. REP, No. 1097, 90th Cong., 2d Sess. 102 (1968), reprinted in [1968] U.S. Cods Cong. \& AD. News 2112, 2191. The fourth proposed requirement-a showing that other methods of investigation are likely to be ineffective-is not specifically mandated by the standards set in Berger, but Congress found it to be a widely practiced, common sense safeguard against unnccessary clectronic intrusions on privacy. Id. at 101, reprinted in [1968] U.S. Code Conc. \& $A \mathrm{D}$. News at 2190. Investigative methods other than tracking include visual surveillance, the use of regular search warrants, and questioning or interrogation. Of courve, as Congress noted in the context of electronic eavesdropping, "[m]erely because a normal investigative technique is theoretically possible, it does not follow that it is likely [to succecd]." Id., reprinled in [1968] U.S. Cone Conc. \& AD. Ncws at 2190. The proposed standards contemplate a common sense approach that limits the use of beepers to situations in which tailing is necessary and visual observation is not practicable. Finally, the required showing of exigency to justify withholding notice is drawn directly from Berger's mandated procedures for oral interception. See p. 1506 supra.

201. These requirements are based on 18 U.S.C. $\$ 2518(4)(1970)$. The first four are intended to limit the scope of the search. See S. REP. No. 1097, 90th Cong., 2d Sess. 103 (1968), reprinled in [1968] U.S. CodE CoNG. \& AD. News 2112, 2192. In many cases the police may be unable to describe with particularity the movements they intend to monitor. 
Because beepers use radio waves subject to federal regulations, these standards may be mandated for both federal and state law enforcement agencies. ${ }^{202}$ Although these requirements go beyond the minimum standards set by the Supreme Court in Berger and Katz, they parallel the requirements of Title III. The same reasons that motivated Congress to impose statutory constraints upon wiretapping and oral interception militate in favor of its adopting a similar statutory framework for electronic tracking. Such a statute would provide a uniform set of guidelines for police and courts alike. It would also give legislative recognition to the privacy interests that would be jeopardized by widespread use of the beeper. ${ }^{203}$ It may be that a person's location and movements are more frequently matters accessible to the public than are his conversations, but he should be as free to preserve the privacy of the one as of the other, without fear that his control over his own privacy will be secretly wrested from him by an electronic device.

Presumably they would not be interested in electronic tracking if the destination and route of travel were known. But it should be possible for police to make some estimate of the extent of the travels they intend to monitor-whether, for example, they expect to track the suspect across town or across the country. Requiring such a particularization, as well as provisions for return on the warrant, would enable judicial supervision to continue throughout the course of the tracking operation. Thus, if the search exceeded its bounds, the magistrate would be able to revise or rescind the order in light of the circumstances. This, together with the time limitation, should ensure that the intrusiveness of the search is minimized.

Similarly, although it may be difficult for police to predict the best method for attaching a beeper, judicial control over this aspect of the search should be particularly strict, in order to guard against unnecessary invasions of privacy resulting from multiple surreptitious intrusions, and to minimize the degree of intrusion caused by installation. See United States v. Ford, 414 F. Supp. 879, 884-85 (D.D.C. 1976), aff'd, 45 U.S.L.W. 2411 (D.C. Cir. Feb. 11, 1977).

Time requirements for electronic tracking usually should be shorter than those customarily permitted for oral interception. In most of the beeper cases decided thus far, tracking was necessary only for a few days. A court order such as the one issued for 30 days in United States v. Pretzinger, 542 F.2d 517, 519 (9th Cir. 1976) (per curiam), is probably overinclusive for most purposes. Although time limitations may not be a current problem due to the limits of present technology, see note 3 supra, court orders in the future must be careful to specify tracking periods that are reasonably limited to law enforcement needs. Moreover, as is the case with wiretapping orders, particular care should be exercised with respect to warrant renewals. See 18 U.S.C. $\$ 2518(1)(f)(1970)$. Provisions for subsequent notice are necessary for compliance with FED. R. CRIM. P. 41(d).

202. See 47 U.S.C. $\$ 301$ (1970) (asserting federal control over interstate radio communications, intrastate communications that affect or interfere with interstate communications, and communications from "mobile stations"); $f$. Omnibus Crime Control and Safe Streets Act of 1968, Pub. L. No. 90-351, tit. III, \$ 801 (a), 82 Stat. 211, reprinled following I8 U.S.C. $\$ 2510(1970)$ (congressional finding that wire communications used inseparably for both interstate and intrastate communications).

203. Cf. Omnibus Crime Control and Safe Strects Act of 1968, Pub. L. No. 90-351, tit. III, $\$ 801(\mathrm{~b})$, (d), 82 Stat. 2I1, reprinted following 18 U.S.C. $\$ 2510$ (1970) (congressional findings concerning threat of electronic eavesdropping to personal privacy). 